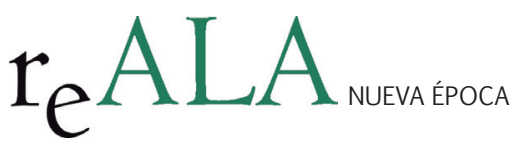

REALA, nº 4, julio-diciembre 2015 ISSN: 1989-8975

DOI: http://dx.doi.org/10.24965/reala.voi4.10302

\title{
Los consorcios locales: ¿Tienen potestad tributaria?
}

\author{
Manuel Alías Cantón \\ Diputación de Almería \\ maliasca@dipalme.org
}

\section{Resumen}

La figura del consorcio local y su consideración como Entidad local, ha sido un tema sujeto a constante discusión, tras la entrada en vigor de la Ley Reguladora de las Bases del Régimen Local, de 1985. Esta discusión se ha acrecentado aún más, si cabe, desde la entrada en vigor de la Ley de racionalización y sostenibilidad de la Administración Local. Junto a lo anterior, la potestad tributaria del consorcio, es otro asunto que genera una constante discusión. Este trabajo pretende poner de manifiesto, no sin cierta controversia, que el consorcio no es una Entidad local —porque el legislador básico estatal así lo quiso-y por tanto no puede gozar de potestad tributaria alguna.

Palabras clave

Consorcio, entidad local, potestad tributaria, voluntad del legislador, reserva de ley.

\section{Local consortia: Do they have tax authority?}

\section{Abstract}

The local Consortium and its consideration as Local Authority has been a topic under constant discussion since Law, of 1985, regulating Local Regimen Bases came into forced. This discussion has increased even more when the Law of rationalization and sustainability of the Local Administration came into force. In addition to that, the taxing rights of the Consortium, is another issue that generates constant debate. This work tries to point out, although with some controversy, that the Consortium is not a Local Authority - because the basic central government legislator wanted to be this way — and, therefore, it cannot have any tax rights.

Keywords

Consortium, local authority, tax rights, legislator will, reserved to law. 
SUMARIO: 1. Introducción. 2. El consorcio como Entidad local. 2.1. Orígenes y evolución de los consorcios locales. 2.2. La naturaleza jurídica del consorcio local. 2.3. El consorcio como Entidad local en la normativa autonómica. 2.4. Pronunciamientos judiciales relativos al consorcio como Entidad local. 3. Potestad tributaria de los consorcios formados por entidades locales. 3.1. Cuestiones generales relativas a la potestad tributaria de las entidades locales. 3.2. Impuestos. 3.3. Tasas. 3.4. Contribuciones Especiales. 3.5. Precios Públicos. 4. Conclusiones. 5. Bibliografía.

\section{INTRODUCCIÓN}

Andaba buscando, en la página web del Tribunal de Cuentas dedicada a la rendición de cuentas de las Entidades locales, el grado de rendición de cuentas de las distintas Entidades locales, cuando en el apartado de información general, me topé con la siguiente pregunta ¿Qué es una Entidad local? El Tribunal de Cuentas, responde a la citada pregunta de la siguiente manera: «Las Entidades locales constituyen la Administración local que es la más cercana a los ciudadanos y está formada fundamentalmente por las Provincias, los Municipios y las Islas (Entidades locales territoriales, cuya existencia es necesaria o imperativa). Además, existen otras Entidades locales formadas por la Agrupación de Municipios tales como Mancomunidades, Comarcas y Áreas metropolitanas, y otras de ámbito territorial inferior al municipal como las Juntas vecinales, Parroquias, etc. Las Entidades locales también pueden constituir consorcios.» Es decir, según el citado Tribunal, hay entidades locales de ámbito territorial, de existencia obligatoria, como son las Provincias, los Municipios y las Islas; hay entidades locales formadas por agrupación de Municipios, como son Mancomunidades, Comarcas y Áreas metropolitanas, y otras de ámbito territorial inferior al municipal; y además la Entidades locales pueden constituir consorcios. Llegados a este punto inmediatamente surge la pregunta entonces ¿el consorcio es una Entidad local, o no lo es?

Aunque no es el objeto de este trabajo, y con el simple objeto de disipar la curiosidad que le pueda surgir al lector, el grado de rendición de cuentas del ejercicio de 2013, a 30 de junio de 2015 era el siguiente: Diputaciones, el 100,00\%; Ayuntamientos, el 91,96\%; Cabildos y Consejos Insulares, el 100,00\%; Comarcas, el 100,00\%; Mancomunidades, el 65,96\%; Áreas metropolitanas, el 100,00\%; Entidades locales menores, el 95,20\%; y consorcios el 48,23\%. Estos datos no incluyen a las entidades de Navarra y País Vasco.

Entonces pensé, vamos a ver qué información suministra el Ministerio de Hacienda y Administraciones Públicas sobre los consorcios.

En el apartado relativo a la Deuda Viva de las Entidades Locales, resulta que el Ministerio ofrece datos sobre datos sobre: Deuda viva de las Diputaciones de Régimen Común, Diputaciones de Régimen Foral, Consejos y Cabildos insulares; datos sobre Ayuntamientos; y datos sobre Entidades de ámbito territorial inferior al municipal, Comarcas u otras Entidades que agrupen varios municipios, Áreas Metropolitanas, Mancomunidades de Municipios. Como se puede ver, ninguna referencia a los consorcios.

En la Base de Datos General de Entidades Locales, podemos leer lo siguiente: «El ámbito de análisis se refiere al Subsector Público Local. La Base de datos General de EELL contempla la estructura de entes dependientes que permite a las Entidades Locales organizar la gestión de sus servicios de acuerdo con el principio de descentralización.» Seguidamente, realiza una clasificación entre Entidades locales y Entes dependientes, a su vez, estos últimos los clasifica en Organismos autónomos, Sociedades mercantiles y Participación de las Entidades locales en, y en esta última clasificación es donde figuran los consorcios, junto con las Fundaciones y las Instituciones sin ánimo de lucro. Posteriormente, al definir los consorcios, dice: «En definitiva, a partir de la LBRL el consorcio es una forma de cooperación de las Administraciones Públicas y una forma de gestión de los servicios públicos locales, así según el Art. 87 de la mencionada Ley: ... » Es decir, para el Ministerio de Hacienda y Administraciones Públicas los consorcios no son Entidades locales, sino una forma de cooperación interadministrativa para la gestión de los servicios públicos locales. Llegados a este punto vuelve a surgir la pregunta entonces ¿el consorcio es una Entidad local, o no lo es?

En el Informe de la IGAE, sobre el Sector Público Empresarial y Fundacional - Composición y Estructura 2010, podemos leer lo siguiente:

«Desde una perspectiva jurídica, el consorcio ha vivido un proceso evolutivo en el que pueden distinguirse tres fases:

REALA, n 4, julio-diciembre 2015, ISSN: 1989-8975 - DOI: http://dx.doi.org/10.24965/reala.v0i4.10302 
i) La primera fase se caracteriza por la consideración del consorcio como un ente local o un ente asociativo para la defensa de intereses locales. Las Bases del Estatuto de Régimen Local (Ley 41/1975, de 19 de noviembre) reconocen ya a esta figura como una entidad local;

ii) La segunda fase, se caracteriza por la superación de la calificación del consorcio como entidad local y por su consideración como un ente asociativo para la gestión de intereses comunes, singularmente de los entes locales y de las Comunidades Autónomas. En esta fase, el consorcio va a ser reconocido, no sólo por las normas de régimen local, sino también por las generales de régimen jurídico de las administraciones públicas, aunque sin definir con precisión su singular naturaleza jurídica. Así, con la entrada en vigor de la Ley 7/1985, de 2 de abril, Reguladora de las Bases del Régimen Local (LBRL), se inicia el proceso de desvinculación de la figura del consorcio.

iii) La tercera fase, desde el año 2000 hasta hoy, se define por el extraordinario desarrollo de la figura consorcial en el ámbito autonómico y por la necesidad de poner límite a un proceso de generación casi espontánea que ha alcanzado un nivel preocupante, sobre todo en términos de control presupuestario (...). La legislación reciente ha introducido novedades muy relevantes en el régimen jurídico de los consorcios administrativos (...). Los aspectos más importantes de esta nueva legislación son los siguientes: Todos los consorcios deben estar adscritos de manera clara y expresa, según sus estatutos, a una Administración Pública de las consorciadas, en concreto a aquella que ejerza un mayor control sobre el consorcio, en función de los criterios que la Ley señala al efecto.»

Como se puede apreciar, para la IGAE, el consorcio ha pasado de ser considerado como una Entidad local —en su primera fase_-; a ser un ente asociativo para la gestión de intereses comunes de las Entidades locales y las Comunidades Autónomas — segunda fase-; y a ser un ente adscrito a una Entidad local, de manera específica a la Entidad local que ejerza un mayor control sobre el consorcio. Llegados a este punto una vez más vuelve a surgir la pregunta entonces ¿el consorcio es una Entidad local, o no lo es?

Si la respuesta a la pregunta, antes formulada, fuera que el consorcio si es una Entidad local, emerge otra pregunta entonces ¿el consorcio tiene potestad tributaria? y si la respuesta fuera que el consorcio no es una Entidad local, de igual manera emerge otra pregunta ¿entonces las tasas y precios públicos que vienen exaccionando, tienen cobertura legal? En definitiva, tal y como acertadamente plantea BLASCO DELGADO', en nuestro ordenamiento jurídico: «sólo los entes públicos, estatales, autonómicos o locales, tienen reconocida la potestad tributaria, por lo que queda claro entonces que el camino que hay que recorrer para saber si un Consorcio local puede establecer una tasa es determinar, en primer lugar, si conforme a su naturaleza y composición puede considerarse per se una entidad pública local, y en segundo lugar, si como tal, puede llevar a cabo alguna de las actividades que, según el TRLRHL, posibilitan la implantación y exigencia del correspondiente tributo.»

Junto a lo anterior, merece la pena indicar que la reciente legislación ha introducido novedades muy relevantes en el régimen jurídico de los consorcios, como consecuencia de los distintos Informes de fiscalización de los consorcios de ámbito local, emitidos por Tribunal de Cuentas, en los que se constataba la insuficiente regulación legal de estas entidades y la imprecisa redacción de los estatutos de muchos de ellos, que puede ser fuente de inseguridad jurídica. Asimismo, el Informe de la comisión cara a la reforma de las Administraciones Públicas² (Informe CORA), de 21de junio de 2013, ponía de manifiesto la necesidad de introducir una regulación específica y más homogénea de los consorcios.

Este trabajo pretende despejar las preguntas planteadas, a la vista de la siguiente normativa: Ley 7/1985, de 2 de abril, Reguladora de las Bases del Régimen Local (en adelante LRBRL); Real Decreto Legislativo 781/1986, de 18 de abril, por el que se aprueba el texto refundido de las disposiciones legales vigentes en materia de Régimen Local (en adelante TRRL); Real Decreto Legislativo 2/2004, de 5 de marzo, por el que se aprueba el texto refundido de la Ley Reguladora de las Haciendas Locales (en adelante TRLRHL); Ley 58/2003, de 17 de diciembre, General Tributaria (en adelante LGT); Ley 27/2013, de 27 de diciembre, de racionalización y sostenibilidad de la Administración Local (en adelante LRSAL); Ley 30/1992, de 26 de noviembre, de Régimen Jurídico de las Administraciones Públicas y del Procedimiento Administrativo Común³ (en adelante LRJAPyPAC); y demás normativa de desarrollo de las anteriores; así como a la vista de la abundante doctrina jurídica y científica existente al respecto.

Para finalizar esta introducción, debemos advertir que, a lo largo de este trabajo al referirnos a los consorcios locales, utilizaremos sólo la expresión consorcios.

1 BLASCO DELGADO (2009): 2

2 El 26 de octubre de 2012 el Consejo de Ministros aprobó un Acuerdo por el que se crea una Comisión para la reforma de las Administraciones Públicas.

3 La LRJAPyPAC, ha sido derogada por la Ley 39/2015, de 1 de octubre, del Procedimiento Administrativo Común de las Administraciones Públicas, que entrará en vigor el 2 de octubre de 2016.

REALA, n 4, julio-diciembre 2015, ISSN: 1989-8975 - DOI: http://dx.doi.org/10.24965/reala.v0i4.10302 


\section{EL CONSORCIO COMO ENTIDAD LOCAL}

\subsection{Orígenes y evolución de los consorcios locales}

Sin ánimo de ser exhaustivos, podemos decir que el origen de los consorcios, se halla en el artículo 172.20 del Reglamento de organización, funcionamiento y régimen jurídicos de las corporaciones locales, aprobado por el Decreto de 17 de mayo de 1952, que establecía lo siguiente: «En congruencia con las atribuciones encomendadas a la Diputación por los artículos 270 y concordantes de la Ley, les corresponderá:... Constituir consorcios con los Ayuntamientos de la Provincia para la construcción de Escuelas y viviendas de Maestros, repoblaciones forestales, tendidos de redes de energía eléctrica, suministros de aguas y demás servicios u obras que afecten a varios Municipios.» Con posterioridad, y de manera más general, el artículo 37.1 del Decreto de 17 de junio de 1955 por el que se aprueba el Reglamento de Servicios de las Corporaciones locales, estableció que: «Las Corporaciones locales podrán constituir consorcios con Entidades públicas de diferente orden, para instalar o gestionar servicios de interés local.» Como se puede apreciar, originariamente en 1952, los consorcios sólo podían estar constituidos por las Diputaciones provinciales y los Ayuntamientos, posteriormente en 1955, los consorcios sólo podían estar constituidos por Corporaciones locales y entidades públicas, estando vedada la participación de entidades privadas en ambos casos. Más tarde, la base 39.4 de la Ley 41/1975, de 19 de noviembre, de Bases del Estatuto de Régimen Local, señalaba que: «Las Entidades Locales, en la forma que se establezca, podrán constituir consorcios con Entidades Públicas de diferente orden o naturaleza, para fines de interés para las respectivas poblaciones. Los consorcios gozarán de personalidad jurídica propia y de la consideración de Entidades Locales.» Dicha Ley fue derogada por la Disposición derogatoria de la LRBRL.

Debe destacarse, tal y como hace PÉREZ TORRENTE4, en relación con la figura del consorcio en el Reglamento de 1955, antes citado, que: «Aun cuando la finalidad del consorcio era la de gestionar servicios públicos locales, no debe entenderse que se trata de una forma de gestión de servicios públicos, al mismo nivel que las formas de gestión directa o indirecta enumeradas en los artículos 67 y 113 del Reglamento.»

La figura de los consorcios, cambió de manera radical con la entrada en vigor de la LRBRL, al establecer la redacción original del artículo 87, lo siguiente: «Las entidades locales pueden constituir consorcios con otras Administraciones públicas para fines de interés común o con entidades privadas sin ánimo de lucro que persigan fines de interés público, concurrentes con los de las Administraciones públicas.» El artículo 110.1 del TRRL, en términos similares, estableció que: «Las Entidades pueden constituir consorcios con otras Administraciones públicas para fines de interés común o con entidades privadas sin ánimo de lucro que persigan fines de interés público concurrentes con los de las Administraciones públicas.» Como vemos el cambio fue doble: por un lado, se admite la posibilidad de que las entidades privadas sin ánimo de lucro formen parte de los consorcios y, por otro lado, extrae a los consorcios de la gestión de servicios públicos y se refiere genéricamente a fines de interés púbico común. De tal suerte que cualquier actividad de las entidades locales, en cuya realización pueda concurrir con otras entidades públicas o privadas sin ánimo de lucro, pueden figurar entre los fines del consorcio.

Por otra parte, la redacción original del artículo 57 de la LRBRL, establecía que: «La cooperación económica, técnica y administrativa entre la Administración Local y las Administraciones del Estado y de las Comunidades Autónomas, tanto en servicios locales como en asuntos de interés común, se desarrollará con carácter voluntario, bajo las formas y en los términos previstos en las leyes, pudiendo tener lugar, en todo caso, mediante los consorcios o convenios administrativos que suscriban.» El contenido de dicho artículo nos lleva a afirmar que, tras la entrada en vigor de la LRBRL, el consorcio pasa de ser un instrumento para la gestión de servicios de interés local, a ser un instrumento de las relaciones de cooperación entre administraciones públicas. A mayor abundamiento, debemos recordar que el artículo 85.2 de la LRBRL, establece todas las formas de gestión directa e indirecta de los servicios públicos de competencia local, y en dicho artículo no se menciona al consorcio.

Adicionalmente, debemos decir que los artículos 42 a 44 de la LRBRL, establecían que correspondería a las Comunidades Autónomas legislar sobre el ámbito territorial, la composición y funcionamiento de los órganos de gobierno, los recursos y el régimen económico de las otras entidades locales —comarcas, áreas metropolitanas, entidades municipales asociativas y demás entidades supramunicipales-y, sobre todo, sobre el procedimiento de aprobación de los estatutos de las mancomunidades. En esta enumeración de entidades locales no se hace alusión alguna a la figura del consorcio.

Hoy en día, la entrada en vigor de la LRSAL, ha supuesto una importante modificación de la figura del consorcio. La nueva redacción del artículo 26.2 de la LRBRL, relativo a los servicios mínimos de prestación obligatoria por parte de los municipios menores de 20.000 habitantes, establece que: «Para coordinar la citada prestación de

4 PÉREZ TORRENTE (1998): 52.

REALA, n 4, julio-diciembre 2015, ISSN: 1989-8975 - DOI: http://dx.doi.org/10.24965/reala.v0i4.10302 
servicios la Diputación propondrá, con la conformidad de los municipios afectados, al Ministerio de Hacienda y Administraciones Públicas la forma de prestación, consistente en la prestación directa por la Diputación o la implantación de fórmulas de gestión compartida a través de consorcios, mancomunidades u otras fórmulas.» Esta redacción es consecuencia del Dictamen del Consejo de Estado de 26 de junio de 2013, que ponía en duda la constitucionalidad de la redacción dada a dicho artículo en el anteproyecto de la LRSAL. Con posterioridad, el Dictamen del Consejo de Estado de 22 de mayo de 2014, en relación con la interposición de un conflicto en defensa de la autonomía local, vuelve a poner en tela de juicio la constitucionalidad del artículo 26.2 de la LBRL, dictaminando que: «nada debería impedir que se opte por una "gestión compartida" de los servicios mínimos obligatorios previstos en el reiterado artículo 26.2.»

Y al artículo 57 de la LRBRL, se le han añadido dos apartados más, en virtud de la LRSAL, resultando de especial interés el nuevo apartado 3, del siguiente tenor literal: «La constitución de un consorcio solo podrá tener lugar cuando la cooperación no pueda formalizarse a través de un convenio y siempre que, en términos de eficiencia económica, aquélla permita una asignación más eficiente de los recursos económicos. En todo caso, habrá de verificarse que la constitución del consorcio no pondrá en riesgo la sostenibilidad financiera del conjunto de la Hacienda de la Entidad Local de que se trate, así como del propio consorcio, que no podrá demandar más recursos de los inicialmente previstos.»

Como se ha dicho, tras la entrada en vigor de la LRBRL, en su redacción original, el consorcio pasa de ser un instrumento para la gestión de servicios de interés local, a ser un instrumento de las relaciones de cooperación entre administraciones públicas. Ahora bien, una vez promulgada la LRSAL, esta afirmación, debe ser puesta en relación con el nuevo contenido de los artículos 26.2 de la LRBRL (servicios de prestación obligatoria por los municipios por la Diputación provincial), y 57 de dicha Ley (cooperación interadministrativa); así como con la Disposición adicional decimotercera de la LRSAL (consorcios constituidos para la prestación de servicios mínimos), que permite la gestión consorciada de los servicios mínimos obligatorios de los municipios de menos de 20.000 habitantes. En este sentido, JIMÉNEZ ASENSIO5, opina que el consorcio: «aunque no se configure expresamente como una forma de gestión directa o indirecta de los servicios públicos, nada debería impedir utilizarla en el marco de lo previsto en los citados artículos y para la prestación de cualquier tipo de servicios locales derivados de las competencias propias, delegadas o "impropias" de cada entidad local.»

Con posterioridad a la entrada en vigor de la LRSAL, se promulgó la Ley 15/2014, de 16 de septiembre, de racionalización del Sector Público y otras medidas de reforma administrativa, que procedía a regular, en el marco de las medidas del Informe $\mathrm{CORA}^{6}$, el régimen jurídico del derecho de separación de los miembros del consorcio administrativo y, cuando ello dé lugar a su disolución (artículos 12 a 15). Esta regulación, la podemos considerar como efímera, pues la propia exposición de motivos de la citada Ley, señala que: «Posteriormente, en la futura Ley de Régimen Jurídico de las Administraciones Públicas, se incluiría un régimen integral (creación, adscripción, funcionamiento, disolución) y básico referido a los consorcios, que derogaría esta regulación y lo previsto en la Ley 27/2013, de 27 de diciembre, de racionalización y sostenibilidad de la Administración Local.»

La voluntad del legislador, de realizar una nueva regulación integral del consorcio administrativo, ha tenido su plasmación en la Ley 40/2015, de 1 de octubre, de Régimen Jurídico del Sector Público, que entrará en vigor el 2 de octubre de 2016. Dicha Ley, dedica sus artículos 118 a 127, a regular la creación, adscripción, funcionamiento, disolución de los consorcios administrativos. Esta Ley, además de derogar la LRJAPyPAC, en el ámbito estrictamente local, deroga el artículo 110 del TRRL y el artículo 85 de la LRBRL.

\subsection{La naturaleza jurídica del consorcio local}

Uno de los principales problemas existentes en la actualidad, es determinar la naturaleza jurídica del consorcio. Cuestión que no es baladí, pues en España existen 308 consorcios de ámbito local, según la IGAE7 y 1.167, incluyendo los participados por las Comunidades Autónomas, según el Tribunal de Cuentas ${ }^{8}$. Tal y como señala TOSCANO GIL ${ }^{9}$, «se trata de una cuestión que ha recobrado importancia con la reforma.» añadiendo a continuación que: «el problema de la naturaleza jurídica del consorcio viene dado por la diversidad de Administraciones Públicas, incluso entidades que no son Administración, que pueden formar parte del mismo».

\section{JIMÉNEZ ASENSIO (2014a): 3.}

6 El Informe CORA fue asumido por el Consejo de Ministros el 21 de junio de 2013.

7 Informe de la IGAE, sobre el Sector Público Empresarial y Fundacional - Composición y Estructura 2010, el Ministerio de Hacienda y Administraciones Públicas sobre los Consorcios, Madrid, 2010, pág. 25.

8 Informe de fiscalización de los Consorcios de ámbito local, n. ${ }^{\circ}$ 1016, Tribunal de Cuentas, Madrid, 2013, pág. 33.

9 TOSCANO GIL (2015). 
Desde este momento debemos decir que el consorcio tiene base asociativa especial y que dicha base asociativa, por lo que respecta a las Entidades locales, tiene su fundamento en el derecho de asociación recogido en el artículo 10.1 de la Carta Europea de Autonomía Local, de 15 de octubre de 1985, que establece que: «las entidades locales tienen el derecho, en el ejercicio de sus competencias, de cooperar y, en el ámbito de la ley, asociarse con otras entidades locales para la realización de tareas de interés común.».

Los consorcios reúnen las siguientes características comunes: Son entidades con personalidad jurídica propia; están sujetos al Derecho administrativo en la medida de que son Administración públicas; son heterogéneos en su composición; y son un instrumento voluntario de cooperación económica, técnica y administrativa entre los distintos niveles de la Administración Pública (Estatal, Autonómica y Local). El consorcio adquiere y, por tanto, dispone de capacidad de obrar, y es sujeto de derechos y obligaciones por el mero acuerdo de aprobación de sus estatutos, sin que exista norma general que obligue a su inscripción en registro alguno. Sólo en Andalucía y Cataluña, la normativa autonómica exige que sus estatutos se homologuen o supervisen por la Comunidad Autónoma. Esta situación ha llevado a decir al Tribunal de Cuentas ${ }^{10}$ que: «a diferencia del consorcio, la sociedad mercantil adquiere su plena personalidad jurídica tras la calificación e inscripción de sus estatutos en el Registro Mercantil, y por ello, una asociación de entidades locales constituida con forma de sociedad mercantil objetivamente presenta mayor seguridad jurídica que si se constituye bajo la forma de consorcio.».

Es una cuestión admitida, de manera pacífica, que el consorcio es una Administración Pública, ya que el artículo 2.1 de la LRJAPyPAC señala que: «Las Entidades de Derecho Público con personalidad jurídica propia vinculadas o dependientes de cualquiera de las Administraciones Públicas tendrán asimismo la consideración de Administración Pública.» En igual sentido, la Ley 5/2010, de 11 de junio, de Autonomía Local de Andalucía, establece que: «el consorcio es una entidad pública sometida al Derecho Administrativo.» Pero entendemos que esto no quiere decir, per se, que deba ser considerado como una Entidad local.

Antes de abordar la normativa sobre régimen local y sobre régimen jurídico de las administraciones públicas, hay que señalar, que la Ley Orgánica 2/2012, de 27 de abril, de Estabilidad Presupuestaria y Sostenibilidad Financiera, tampoco hace referencia a la naturaleza jurídica del consorcio al enumerar las unidades que integran el sector público, limitándose a decir en su apartado 2 -tras citar como integrantes del sector público a la Administración central, que comprende el Estado y los organismos de la Administración central, las Comunidades Autónomas; las Corporaciones Locales, y la Administraciones de Seguridad Social-, que: «El resto de las entidades públicas empresariales, sociedades mercantiles y demás entes de derecho público dependientes de las administraciones públicas, no incluidas en el apartado anterior, tendrán asimismo consideración de sector público... » No obstante, para CORCUERA TORRES ${ }^{11}$ el consorcio, es una entidad local pues se encuentra clasificado como un ente dependiente dentro del «Inventario de Entes del Subsector Público Local».

Tampoco el Derecho de la Unión Europea nos ayuda a determinar la naturaleza jurídica del consorcio, pues aunque existen figuras de colaboración interadministrativa con las que el consorcio tiene evidentes similitudes, como son las Agrupaciones Europeas de Interés Económico —reguladas en el Reglamento n. ${ }^{\circ} 2137 / 85$, de 25 de julio de 1985-y, especialmente, las Agrupaciones Europeas de Cooperación Territorial —reguladas en el Reglamento n. ${ }^{\circ} 1082 / 2006$, de 5 de julio de 2006 - nada dice de manera específica sobre el consorcio.

La doctrina científica no ha mantenido una posición unánime, ni muchos menos, en relación con la figura del consorcio. Entre los que defienden la posición de que el consorcio es una Entidad local, encontramos a MARTíN $M^{M A T E O}{ }^{12}$, que dice: «a pesar de todo creemos que el régimen real del consorcio no ha sufrido alteraciones sustanciales con la nueva legislación y que siguen siendo Entidades locales...» Por el contrario, entre los que defienden que el consorcio no es una Entidad local, encontramos a CASTILLO BLANCO ${ }^{13}$, que señala que: «los consorcios no tienen la condición de Entidades locales». Existe otro sector de la doctrina que sostiene una postura intermedia, como es el caso de MAS RIGO ${ }^{14}$, para el que la solución a si el consorcio es un ente local: «vendrá determinada por el hecho de que actividades o servicio público objeto del consorcio se halle incluido o no dentro del ámbito de competencias propias de las entidades locales.» O SOSA WAGNER ${ }^{15}$, el cual considera que para que el consorcio local participado por Administraciones Públicas no locales sea un ente local: «es necesario, tanto que la presencia de estas otras Administraciones en los órganos de gestión del mismo no resulte determinante, como que el servicio o los servicios gestionados por el consorcio se incluyan claramente dentro del ámbito de las

\footnotetext{
10 Informe de fiscalización de los Consorcios de ámbito local, n. 1016, Tribunal de Cuentas, Madrid, 2013, pág. 23.

11 CORCUERA TORRES (2005): 29-32.

12 MARTÍN MATEO (1987): 112.

13 CASTILLO BLANCO (1991): 124.

14 MAS RIGO (2003): 25.

15 SOSA WAGNER (2008): 372.
}

REALA, n 4, julio-diciembre 2015, ISSN: 1989-8975 - DOI: http://dx.doi.org/10.24965/reala.v0i4.10302 
competencias locales.» Y, por último, hay un sector, en el que se encuentra RIVERO YSERN ${ }^{16}$, que considera que: «el consorcio tras la publicación de la LRBL puede ser considerado tanto como una Entidad local como Entidad de Derecho público de naturaleza asociativa y de constitución en todo caso asociativa.».

Llegados a este punto — teniendo presente todo lo dicho con anterioridad — debemos posicionarnos sobre, sí el consorcio es una Entidad local, o no lo es. La respuesta es, que el consorcio no es una Entidad local, asumiendo que esta postura es la minoritaria. El argumento principal para inclinar la balanza, lo hemos encontrado en el Diario de Sesiones del Congreso de los Diputados. Así, el proyecto de LRBRL, publicado en el Boletín Oficial de las Cortes-Congreso Diputados, de 3 de abril de 1984, no incluía dentro del artículo 3.2 al consorcio como entidad que gozara, asimismo, de la condición de entidad local. En el Boletín Oficial de las Cortes-Senado, 21 de diciembre de 1984, se publicaron las enmiendas al articulado del proyecto de Ley. Entre dichas enmiendas, encontramos la n. ${ }^{\circ}$ 223, relativa al artículo 3.2, con el siguiente contenido: «De adicción. Añadir un apartado e) con el siguiente texto: e) los consorcios», cuya justificación era: «La necesidad de incluir a los consorcios como entidades locales.» Dicha enmienda fue rechazada no sólo con el argumento de que «no tienen la misma naturaleza jurídica que las demás entidades locales» contempladas en el art. 3.2, sino porque, además, «no están olvidados los consorcios en la ley».

Es evidente, público y notorio — para cualquiera que haya leído los Diarios de sesiones del Congreso y del Senado, con ocasión de la tramitación de la LRBRL - que en la voluntad mayoritaria del Legislativo opto por excluir al consorcio de la condición de Entidad local. Al respecto, COBO OLVERA ${ }^{17}$, señala lo siguiente: «De un análisis de dicho artículo, se deriva con bastante claridad que la intención del legislador de 1985 ha sido la de no conceder al consorcio el carácter de Entidad local.».

Aunque no sea el objeto de este trabajo, nos vamos a permitir hacer un breve comentario sobre la interpretación de las normas y para ello vamos a utilizar lo expuesto por SÁNCHEZ-OSTIZ ${ }^{18}$, que dice: «El contenido del texto no es meramente gramatical, sino que, como toda obra humana, el texto de la ley tiene un autor, y por tanto es producto de una voluntad o finalidad que es aquello que la norma pretende.» La interpretación se lleva a cabo con la ayuda de los cuatro cánones clásicos: gramatical, histórico, sistemático y teleológico. Si atendemos al sentido gramatical de la LRBRL, según el sentido de sus palabras, nada dice sobre la consideración del consorcio como Entidad local. Si atendemos al sentido sistemático de la LRBRL, según el sentido que un término posee en el contexto en el que se emplea (artículo, capítulo, sección, título, ley), se desprende que el artículo 87 de la LRBRL, relativo a los consorcios, se encuentra en el Título VI, bajo la rúbrica «Bienes, actividades y servicios y contratación», mientras que el artículo 3 que enumera las Entidades locales, se encuentra en el Título I, bajo la rúbrica «Disposiciones generales». Si atendemos al sentido histórico, atendiendo a los debates parlamentarios, las diferencias entre texto del proyecto de ley y la ley aprobada finalmente, para indagar la voluntad del legislador, ¿qué quiso decir y qué no quiso decir el legislador al emplear esos y no otros términos? resulta que, de la lectura de los debates parlamentarios, se desprende la voluntad inequívoca del legislador de excluir de la consideración de Entidad local al consorcio. Y finalmente, si atendemos al sentido teleológico, como principio inspirador que aporta sentido, buscando el fin que busca la norma y el fin que busca el legislador (voluntas legislatoris o mens legislatoris), también llamada interpretación subjetiva, resulta que lo que pretendió el legislador, cuando aprobó la LRBRL, fue excluir al consorcio de la consideración de Entidad local.

Junto al argumento principal, antes reseñado, nos ayuda a reafirmarnos en nuestra posición de negar el carácter de Entidad local al consorcio el hecho de que el TRRL, de manera coherente con la LRBRL, no incluye entre las Entidades locales al consorcio, refiriéndose a este último en su artículo 110, en los términos señalados con anterioridad. Asimismo, nos reafirma en nuestro posicionamiento, el hecho de que ni el Real Decreto 1690/1986, de 11 de julio, por el que se aprueba el Reglamento de Población y Demarcación Territorial de las Entidades Locales, ni el Real Decreto 2568/1986, de 28 de noviembre, por el que se aprueba el Reglamento de Organización, Funcionamiento y Régimen Jurídico de las Entidades Locales, hagan referencia alguna al Consocio como Entidad local. No se debe perder de vista, que ambos reglamentos son dictados al amparo de la disposición final primera de la LRBRL, por lo que son normas que desarrollan el contenido de dicha Ley. En este caso, es patente la voluntad del Ejecutivo de no incluir al consorcio como Entidad local.

Por el contrario, la normativa presupuestaria local, sí parece incluir al consorcio dentro de la categoría de Entidad local, aunque estamos hablando de una Orden ministerial, en concreto, la Orden EHA/3565/2008, de 3 de diciembre, por la que se aprueba la estructura de los presupuestos de las entidades locales. Dicha Orden cuando, en la clasificación económica de gastos, enumera las distintas transferencias corrientes a Entidades locales, establece lo siguiente: «467 A consorcios.» y cuando enumera las distintas transferencias de capital a Entidades locales, establece lo siguiente: «767 A 
consorcios.» Asimismo, cuando en la clasificación económica de ingresos, enumera las distintas transferencias corrientes de Entidades locales, establece lo siguiente: «467 A consorcios.» y cuando enumera las distintas transferencias de capital de Entidades locales, establece lo siguiente: «767 A consorcios.» Habría que preguntarse, si el contenido de dicha Orden ministerial, puede decir lo que no dice ni la LRBRL ni el TRLRHL. Pero entonces, tendríamos que realizar un análisis sobre la jerarquía normativa, establecido en el artículo 9.3 de la Constitución, que a nadie escapa, excede con mucho, del contenido de este trabajo. No obstante, no podemos dejar pasar la oportunidad de decir que, según el principio de jerarquía normativa, que consagra el artículo 9.3 de la Constitución, las normas jurídicas se ordenan jerárquicamente, de forma tal que las de inferior rango no pueden contravenir a las superiores, so riesgo de nulidad. Esta jerarquía normativa también se encuentra garantizada en la LRJAPyPAC. En particular, el artículo 51 de dicha Ley, señala que: «2. Ninguna disposición administrativa podrá vulnerar los preceptos de otra de rango superior. 3. Las disposiciones administrativas se ajustarán al orden de jerarquía que establezcan las leyes.».

La LRSAL, introduce la Disposición adicional vigésima, en la LRJAPyPAC, bajo la rúbrica de "Régimen jurídico de los consorcios", cuyo tenor literal es el siguiente: «1. Los estatutos de cada consorcio determinarán la Administración pública a la que estará adscrito, así como su régimen orgánico, funcional y financiero... 3. En el supuesto de que participen en el consorcio entidades privadas sin ánimo de lucro, en todo caso el consorcio estará adscrito a la Administración pública que resulte de acuerdo con los criterios establecidos en el apartado anterior.».

Tras la entrada en vigor de la LRSAL, que ha modificado la LRBRL y la LRJAPyPAC, no cabe duda que los consorcios han acentuado su carácter de ente instrumental, pues como se puede apreciar de las modificaciones introducidas, los consorcios estarán obligatoriamente adscritos a una Administración pública de conformidad con los criterios de adscripción definidos en la disposición adicional vigésima de la LRJAPyPAC. Tal y como señala JIMÉNEZ ASENSIO ${ }^{19}$, a la luz del contenido de la LRSAL: «Cabe dudar que, a partir de la misma, los consorcios puedan ser calificados como entidades locales.».

Además, la LRSAL ha introducido un nuevo artículo 103.bis en la LRBRL, relativo a la masa salarial del personal laboral del sector público local. Dicho artículo distingue entre la propia Entidad Local, organismos, entidades públicas empresariales y demás entes públicos y sociedades mercantiles locales de ella dependientes, así como las de los consorcios adscritos a la misma en virtud de lo previsto en la legislación básica de régimen jurídico de las Administraciones Públicas y de las fundaciones. Es decir, el consorcio se considera una entidad adscrita a la Entidad local —ni siguiere una entidad dependiente de la Entidad local—, y dicha adscripción, se realiza en función de la legislación básica de régimen jurídico de las Administraciones Públicas (LRJAPyPAC) y no en función de la legislación básica del régimen local — LRBRL—, lo que vendría a reafirmar la postura de que el consorcio no es una Entidad local, sino una figura asociativa de Entidades locales, adscrita a una de esas Entidades locales.

\subsection{El consorcio como Entidad local en la normativa autonómica}

Según el Informe de fiscalización de los consorcios de ámbito local, emitido por el Tribunal de Cuentas ${ }^{20}$, «Ni la existencia de consorcios locales con anterioridad a la constitución de las comunidades autónomas ni el progresivo incremento posterior de éstos ha dado lugar, con carácter general, a una regulación autonómica suficiente de dicha figura; bien, porque no todas las comunidades autónomas la hayan regulado, bien, por la poca concreción que se hace de ella en las normas existentes.» En definitiva, se puede afirmar que no existe un criterio único que determine cuándo un consorcio puede ser considerado autonómico o local.

Para que un consorcio pueda ser considerado como Entidad local, es necesaria su calificación como tal por el legislador autonómico. Según TOSCANO GIL ${ }^{21}$, esto es así «por el alto grado de interiorización autonómica al que están sometidas estas entidades, que, según conocida doctrina del Tribunal Constitucional.» El autor, fundamenta su afirmación, entre otras, en la Sentencia del Tribunal Constitucional n. ${ }^{\circ}$ 214/1989, de 21 de diciembre. Las Comunidades Autónomas que en su legislación de régimen local consideran al consorcio como Entidad local, son Andalucía, Galicia e Islas Baleares:

a) Andalucía: La Ley 5/2010, de 11 de junio, de autonomía local de Andalucía, reconoce la condición de Entidad local de cooperación al consorcio local. En su artículo 3.4, admite que: «por Ley, o de acuerdo con la presente Ley, podrán crearse otras entidades locales complementarias». Y en su artículo 78.3, señala que: «se considerarán entidades locales de cooperación territorial a los efectos de esta Ley» cuando se trate de «consorcios participados mayoritariamente por entidades locales y que persigan fines en materia de interés local.».

19 JIMÉNEZ ASENSIO (2014b). 309.

20 Informe de fiscalización de los Consorcios de ámbito local, n. ${ }^{\circ}$ 1016, Tribunal de Cuentas, Madrid, 2013, pág. 16.

21 TOSCANO GIL (2011): 44 . 
b) Galicia: La Ley 5/1997, de 22 de julio, de Administración Local de Galicia, otorga la condición de entidad local no territorial a los consorcios locales. En su artículo 2, establece que: «Gozan de la condición de Entidades Locales no territoriales (... ) los consorcios locales»..

c) Islas Baleares: La Ley 20/2006, de 15 de diciembre, municipal y de régimen local de las Illes Balears, En su artículo 2, señala que: «También tienen la condición de entes locales (...) los consorcios locales constituidos por entes locales entre sí o con otras administraciones públicas y que tengan por objeto esencial la prestación de servicios y obras que sean competencia de los entes locales.».

La Comunidad Autónoma de Aragón, ha realizado una regulación similar a las anteriores, mediante norma de carácter reglamentario como es el Decreto 347/2002, de 19 de noviembre, por el que se aprueba el Reglamento de bienes, actividades, servicios y obras de las entidades locales de Aragón, lo que supondría una extralimitación reglamentaria, pues la Ley 7/1999, de 9 de abril, de Administración local de Aragón, no contempla al consorcio como como Entidad local. Hay que precisar que, el apartado 3 del artículo 321 de dicho Decreto, fue declarado nulo por la Sentencia del TSJ de Aragón 771/2006, de 13 de noviembre, con el siguiente fundamento jurídico: «dicho régimen por lo que se refiere a los consorcios está contenido en el artículo 218 de la citada ley aragonesa, precepto que no establece que dichos consorcios tengan la consideración de Entidades Locales.».

Por nuestra parte compartimos además, de lo dicho por el TSJ de Aragón, lo que expone CASTILLO BLANCO ${ }^{22}$, cuando dice que: «también el legislador autonómico de régimen local también se ha ocupado de delimitar cuando, y con qué requisitos, un consorcio ha de ser considerado como un ente local, bien es cierto que dicha condición de ente local, tras la LRSAL aunque a mi juicio desde antes, no viene amparada por la legislación básica de régimen local.» Por el contrario, GARCÍA RUBIO ${ }^{23}$, considera que la legislación autonómica que atribuye a los consorcios la cualidad de Entidad local: «no contradice la legislación estatal básica, en la medida de que hay que entenderla referida a los supuestos en que el régimen jurídico de adscripción de la entidad es la legislación local.».

Para mayor claridad, conviene traer a colación la Sentencia del Tribunal Constitucional n. ${ }^{\circ} 31 / 2010$, de 28 de junio de 2010, en la que se reconoce la competencia de la Generalidad de Cataluña para legislar en exclusiva sobre las técnicas de cooperación y colaboración entre entidades locales «incluyendo las distintas formas asociativas, mancomunadas, convencionales y consorciales.», si bien con el límite de que compete al Estado al decir que «la remisión que se hace en este punto a las formas asociativas, mancomunadas, convencionales y consorciales ha de presuponer la sujeción a la naturaleza de cada una de ellas, de acuerdo con lo que el Estado, ex art. 149.1.18 CE, establezca en su caso.» Asimismo, la citada Sentencia dice que «en principio ninguna objeción puede formularse a que el Estatuto de Autonomía de la Comunidad Autónoma, en tanto que su norma institucional básica, contenga las líneas fundamentales o la regulación esencial, con el fin de vincular al legislador autonómico, del régimen local en el ámbito territorial la Comunidad Autónoma, debiendo respetar, en todo caso, las previsiones estatutarias, como es obvio, la competencia básica que al Estado corresponde en la materia en virtud de la reserva del art. 149.1.18 CE, por cuanto la expresión “bases del régimen jurídico de las Administraciones públicas” engloba a las Administraciones locales.» En este sentido, el Dictamen 8/2014, de 27 de febrero, sobre la Ley 27/2013, de 27 de diciembre, de racionalización y sostenibilidad de la Administración local, del Consell de Garanties Estatutàries de Cataluña, ha señalado que: «la relación entre las normas estatutarias sobre régimen local y las bases estatales se fundamenta en una prevalencia de estas últimas» De lo anterior, parece desprenderse que si bien las Comunidades Autónomas pueden legislar sobre los consorcios, fijar la naturaleza de los mismos es competencia exclusiva del Estado, en virtud de la reserva del art. 149.1.18 Constitución.

Cuando entran en conflicto una ley estatal y otra autonómica, tal y como ha señalado el Tribunal Constitucional —entre otras en su Sentencia n. ${ }^{\circ}$ 132/2012, de 9 de junio de 2012- «la infracción autonómica de una ley básica estatal se considera, en realidad, como infracción de un título competencial del Estado.» Pero lo cierto, es que las dos leyes en conflicto son válidas mientras no se declare la inconstitucionalidad de una de ellas. En sentido, VELASCO CABALLERO ${ }^{24}$, sostiene que «la Constitución no impone el desplazamiento de la ley autonómica cuando entra en contradicción con la ley estatal.».

\subsection{Pronunciamientos judiciales relativos al consorcio como Entidad local}

La cuestión de la naturaleza jurídica de los consorcios formados por Entidades locales está en permanente debate, siendo muchas las ocasiones en la que distintos Tribunales de Justicia, se han pronunciado en favor de considerar el consorcio como Entidad local. A modo de ejemplo podemos citar las siguientes:

\footnotetext{
22 CASTILLO BLANCO (2014): 893.

23 GARCIA RUBIO (2014): 195.

24 VELASCO CABALLERO (2014): 15.
} 
En Tribunal Supremo en su Sentencia, de 30 de abril de 1999 (recurso 7268/1992), estableció que «La circunstancia de que los consorcios no vengan incluidos como entidades locales en el artículo 3 de la 7/1.985 no impide la caracterización como ente local del consorcio..., ya que la enumeración que verifica el apartado segundo de este precepto no tiene carácter exclusivo (... ) el Texto Refundido de 1986 no ha querido caracterizar a todos los consorcios que puedan constituirse al amparo de su artículo 110 como entidades locales, pero sin negarles tampoco tal consideración, permitiendo que en cada caso, según las circunstancias concurrentes, pueda determinarse si el consorcio constituido es o no una entidad local, existiendo razones —ya expuestas - para atribuir esta naturaleza al consorcio (...) De lo dicho hasta ahora se deduce claramente que esta Sala no ha reconocido a los consorcios el carácter de entidades locales con carácter general, sino solo cuando así se dispone por ley o cuando están constituidos exclusivamente por entidades locales...» Como acertadamente señala TOSCANO GIL 25 , «Esta sentencia vino a decir que si el legislador no había establecido expresamente que el consorcio local era una entidad local, ello era porque la diversidad de entidades que podían formar parte del mismo conducía a que, realmente, la naturaleza jurídica del consorcio administrativo dependiera del caso.».

En Tribunal Supremo en su Sentencia, de 28 de noviembre de 2007 (recurso 5 42/2005), relativa al consorcio de Transportes de Vizcaya, ratificó que los consorcios eran entidades locales aunque «no se hallen incluidos en la enumeración del art. 3 de la LBRL, y ello porque la enumeración de este precepto es "numerus apertus" y además porque, si bien la ley no ha querido caracterizar a todos los consorcios como entidades locales, tampoco les ha negado tal naturaleza jurídica autorizando que, en cada caso y según las circunstancias, pueda determinarse si el consorcio es o no es una entidad local.».

Apartándose, al menos así nos lo parece, del criterio mantenido en su Sentencia de 30 de abril de 1999, el Tribunal Supremo en su Sentencia, de 15 de septiembre de 2011 (recurso 6210/2009), relativa a la Institución Ferial de Madrid (IFEMA), consideró inaplicables las exenciones subjetivas por el Impuesto sobre Sociedades, al negar la condición de entidad local al IFEMA por estar participada por una entidad privada. Esta Sentencia confirma la de la Audiencia Nacional, de fecha 15 de octubre de 2009 (recurso 224/2006) argumentando que: «Ninguna duda razonable se plantea la Sala sobre la imposibilidad de considerar "entidades locales" a los consorcios tras el cambio legislativo operado por la Ley de 1985 y el Texto Refundido de 1986, máxime teniendo en cuenta que a la institución que nos ocupa (IFEMA) se incorporó con posterioridad a la entrada en vigor de tales normas una entidad privada (...) Pese al loable esfuerzo argumentativo de la parte actora por defender que los consorcios siguen teniendo la consideración — después de tales normas—de entidades locales (...) entendemos que si la Ley de Bases de Régimen Local y el Texto Refundido no han reconocido dicha condición es porque, claramente, han decidido excluirla. Además, obvio es decirlo, el legislador de 1985 y 1986 hubo de tener necesariamente en cuenta la normativa que se modificaba, lo que permite entender que la falta de toda referencia al carácter de entidad local de los consorcios suponía, cabalmente, la exclusión de dicha condición.».

La Audiencia Nacional en su Sentencia, de 2 de abril de 2001 (recurso 169/2000), declaró la inembargabilidad de los bienes del consorcio de Abastecimiento de Agua Plan Écija al tener la condición de entidad local. En la citada Sentencia se utiliza como fundamento al Tribunal Supremo en su Sentencia, de 30 de abril de 1999, pero destaca que «En el caso que nos ocupa, como hemos dicho anteriormente, el consorcio de Abastecimientos se constituyó en el año 1975, antes de la vigencia de la actual Ley de Bases de Régimen Local, al amparo de los arts. 37 a 40 del Reglamento de Servicios de las Corporaciones Locales, aprobado por Decreto de 17/7/55, (...) Todas estas circunstancias llevan a la consideración de que el consorcio de abastecimiento de aguas “Plan Écija” es una entidad local.».

La Sentencia de TSJ del País Vasco, de 13 de octubre de 2008 (recurso 340/2007), relativa al consorcio de Aguas de la Rioja Alavesa, señala que: «Sin embargo, una primera visión del vigente derecho positivo lleva a poner en duda ese carácter de Entidad Local que la parte recurrente atribuye a los consorcios, y que no toma fundamento en el artículo $3^{\circ}$ de la Ley de Bases de Régimen Local, ni en los artículos 35 a 45 del Texto Refundido de 18 de Abril de 1.986 dedicándose atención al mismo desde el prisma exclusivo de la prestación de servicios, —articulo 87 LBRL y 110 TR-. Tampoco la Norma Foral alavesa de Haciendas Locales contiene regla alguna que tome específicamente a los consorcios como tales Entidades Locales, ... ».

La Sentencia del TSJ de Baleares, de 11 de febrero de 2011 (recurso 287/2010) comienza diciendo lo siguiente: «Tanto en la LBRL, como en el TRLRL, se contempla a los consorcios como fórmulas de cooperación o colaboración entre Administraciones públicas (o entre la Administración con entidades privadas), de carácter asociativo y voluntario, destinados a fines de interés general y/o la gestión de servicios públicos, regidos por los estatutos que se otorguen. En suma, Véase art. 27.1 Los mismos no se contemplan como entidad o Administración local.» Con

25 TOSCANO GIL (2015).

REALA, n 4, julio-diciembre 2015, ISSN: 1989-8975 - DOI: http://dx.doi.org/10.24965/reala.v0i4.10302 
posterioridad, señala que «Sin embargo, como hemos señalado, la legislación balear contempla estas fórmulas de asociación interadministrativa como verdaderos entes locales, de conformidad con el artículo 3.2 LBRL (...) El legislador balear puede, en el ejercicio legítimo de su autonomía (STC 214/1989, de 21 de diciembre) constituir entidades locales contingentes, pero siempre con respeto a la legislación básica estatal, y, en cuanto al asunto que nos ocupa, dentro de los límites de los artículos 3 y 4 LBRL, reguladores de los tipos de entidades locales» De lo dicho hasta ahora por el TSJ de Baleares, parecía desprenderse que el consorcio no era una Entidad local, pero dicha Sentencia, finalmente establece que «Pues bien, esta constitución de una entidad local de base asociativa, integrada por los Ayuntamientos de los municipios menorquines y el Consell Insular de Menorca, se inserta dentro del supuesto previsto en el artículo 3.2 LBRL, como administración pública (naturaleza de los consorcios locales asimismo refrendada por la Sala Tercera del Tribunal Supremo en Sentencias dictadas el 30 de abril de 1999, recurso de casación n. ${ }^{\circ}$ 7268/1992 y el 18 de septiembre de 2001, recurso de casación n. ³230/1997).».

La Sentencia del TSJ de Madrid, de 23 de marzo de 2012 (recurso 308/2012), relativa a la inscripción en el Registro de Entidades Locales del consorcio de Seguridad, Emergencia, Salvamento, Prevención y Extinción de Incendios de la isla de Lanzarote, que había sido denegada por Secretaría General Técnica del Ministerio de Política Territorial, tras utilizar como fundamento la Sentencia del Tribunal Supremo, de 30 de abril de 1999, establece lo siguiente: «Finalmente no puede dejarse de lado el hecho de que es idéntico al consorcio al que se le reconoció la naturaleza de entidad local en la sentencia del 30/04/99, más arriba comentada. Debiendo por ello llegarse a la misma solución en el supuesto que estamos resolviendo (...) Como quiera que hemos afirmado la naturaleza de ente local del consorcio demandante debemos acoger su pretensión al deber ser inscrito en el Registro como pretende al así venir establecido en la normativa que lo regula».

\section{POTESTAD TRIBUTARIA DE LOS CONSORCIOS FORMADOS POR ENTIDADES LOCALES}

\subsection{Cuestiones generales relativas a la potestad tributaria de las entidades locales}

El artículo 137 de la Constitución establece la organización territorial del Estado en municipios, en provincias y en las Comunidades Autónomas que se constituyan, añadiendo que «Todas estas entidades gozan de autonomía para la gestión de sus respectivos intereses.» Por su parte, el artículo 140 de la Constitución establece que «La Constitución garantiza la autonomía de los municipios.» Vistos dichos preceptos constitucionales podemos decir que el principio de autonomía es uno de los pilares básicos de nuestro Estado. En tal sentido, el Tribunal Constitucional en su Sentencia n. ${ }^{\circ}$ 32/1981, de 28 de julio de 1981 indicó lo siguiente: «El principio de autonomía es uno de los principios estructurales básicos de nuestra Constitución», confirmando su anterior doctrina que establecía que «El principio de autonomía es un principio general de la organización del Estado plasmado en nuestra Constitución.» Ahora bien, como es sabido, la Constitución no proclama de manera expresa la "autonomía financiera" de las Corporaciones locales, como lo hace respecto de las Comunidades Autónomas en su artículo 156, ni el principio de autonomía de las entidades locales se encuentra específicamente referido a la hacienda local, sino que la Constitución únicamente garantiza la autonomía de manera genérica a los municipios en su artículo 140, y se refiere al gobierno y administración autónoma de las provincias en su artículo 141.2.

Los preceptos normativos relativos al sistema tributario local, se dictan en virtud de la competencia exclusiva del Estado reconocida por nuestra Constitución en el artículo 133, de acuerdo con el cual: «1. La potestad originaria para establecer los tributos corresponde exclusivamente al Estado mediante Ley. 2. Las Comunidades Autónomas y las Corporaciones locales podrán establecer y exigir tributos, de acuerdo con la Constitución y las leyes.» $\mathrm{A}$ su vez, el artículo 4 de la LGT, establece que: «1. La potestad originaria para establecer tributos corresponde exclusivamente al Estado, mediante ley. 2. Las comunidades autónomas y las entidades locales podrán establecer y exigir tributos, de acuerdo con la Constitución y las leyes. 3. Las demás entidades de derecho público podrán exigir tributos cuando una ley así lo determine.».

Las Comunidades Autónomas no tienen competencia legislativa respecto al sistema tributario local. En este sentido, la Sentencia del Tribunal Constitucional n. ${ }^{\circ}$ 233/1999, de 16 de diciembre, relativa varios artículos de la Ley 39/1988, de 28 de diciembre de 1988, reguladora de las haciendas locales, estableció la competencia exclusiva del Estado en materia de haciendas locales impidiendo cualquier intervención, en esta materia, por parte de las comunidades autónomas, con base a los artículos de la Constitución: 149.1.18. ${ }^{\text {, }}$ régimen jurídico de las Administraciones Públicas; $149.1 .14 .^{a}$, hacienda general; y 133, que mencionaban la potestad tributaria originaria del Estado. Dichas sentencias, en mayor o menor medida fueron ratificadas por otros pronunciamientos posteriores del Tribunal Constitucional. Más recientemente, este mismo Tribunal, en su Sentencia n. ${ }^{\circ} 31 / 2010$, de 28 de junio de 2010, relativa a varios artículos del Estatuto de Autonomía de Cataluña, declaró inconstitucional la posibilidad de que las Comunidades Autónomas establecieran y regularan tributos propios de los gobiernos locales, argumentando el contenido de los artículos 129 a 142 de la Constitución. 
En definitiva, la potestad en materia de tributos locales es exclusiva del Estado, y como señala JIMÉNEZ COMPAIRED ${ }^{26}$ : «Se trata de una potestad exclusiva y excluyente del Estado que no permite intervención autonómica en la creación y regulación de los tributos propios de las entidades locales.» Ahora bien, hay que tener presente que una cosa es el sistema tributario local, y otra el ordenamiento tributario local, pues este último engloba no solo el conjunto de tributos que conforma el sistema tributario local, sino también las restantes materias relativas a la ordenación e imposición de los tributos locales, de tal suerte que si partimos del hecho de que el artículo 1 del TRLRHL sólo hace referencia al sistema tributario local, el resto del ordenamiento tributario local podría ser objeto de desarrollo normativo por las Comunidades Autónomas.

Debemos preguntarnos si la prohibición, declarada por el Tribunal Constitucional, de que las Comunidades Autónomas establecieran y regularan tributos propios de los gobiernos locales es absoluta o no. Decimos esto porque la Ley Balear 20/2006, de 15 de diciembre, Municipal y de Régimen Local, antes citada, dispone en su artículo 45 que: «Los consorcios locales gozan de la naturaleza de ente local (...) Para el cumplimiento de éstos, están dotados de todas las potestades previstas en la legislación básica de régimen local. La potestad tributaria se concreta en el establecimiento de tasas por prestación de servicios o realización de actividades y la imposición de contribuciones especiales. Asimismo, pueden fijar precios públicos y tarifas.» Si consideramos al consorcio como Entidad local —que por cierto el TRLRHL no le concede ninguna potestad tributaria expresa—, nos resulta difícil de entender que una Ley autonómica le pueda conferir dicha potestad, pero si, por el contrario, no consideramos al consorcio como Entidad local, habría que cuestionarse de manera clara, si la citada Ley desborda el marco constitucional. El TSJ de Baleares, no puso ninguna objeción al contenido del citado artículo 45, con ocasión de su Sentencia de 11 de febrero de 2011.

La potestad tributaria de las entidades locales viene reconocida en los artículos 106.1 de la LRBRL, el cual establece que: «Las Entidades locales tendrán autonomía para establecer y exigir tributos de acuerdo con lo previsto en la legislación del Estado reguladora de las Haciendas locales y en las Leyes que dicten las Comunidades Autónomas en los supuestos expresamente previstos en aquélla.» y 6 del TRLRHL, el cual señala que: «Los tributos que establezcan las entidades locales al amparo de lo dispuesto en el artículo 106.1 de la Ley 7/1985, de 2 de abril, Reguladora de las Bases del Régimen Local...» Dicha potestad tributaria de las Entidades locales, será ejercida a través de Ordenanzas fiscales reguladoras de sus tributos propios y de Ordenanzas generales de gestión, recaudación e inspección, tal y como señalan los artículos 106.2 de la LRBRL y 12.2 del TRLRHL.

Una vez meridiana la potestad exclusiva del Estado para establecer los tributos locales mediante Ley, así como la potestad reglamentaria (ordenanzas fiscales) de las Entidades locales para establecer y exigir dichos tributos conforme a la Ley, debemos analizar la posibilidad de que los consorcios establezcan y exijan tributos, con base al TRLRHL. No obstante, antes de abordar dicha cuestión debemos de incidir en el contenido del artículo 6.5 de la LRJAPyPAC, relativa a los convenios de colaboración, que señala en su segundo inciso lo siguiente: «Los estatutos del consorcio determinarán los fines del mismo, así como las particularidades del régimen orgánico, funcional y financiero.» Es decir, los estatutos del consorcio determinarán las particularidades de su régimen financiero, que como acertadamente indica MÉNDEZ LIMA ${ }^{27}$, es un «concepto no exactamente coincidente con tributario» De manera simple, podemos decir que el régimen financiero se encarga de ordenar los ingresos y los gastos públicos, normalmente previstos en el presupuesto de una Administración pública, mientras que el régimen tributario se encarga de regular la actividad administrativa tendente a la obtención de recursos fundamentada en su poder de imperio, a través de la cual se impone a los particulares la obligación de contribuir a las cargas públicas, normalmente impuestos, tasas, contribuciones especiales y precios públicos.

Para mayor abundamiento de lo expuesto con anterioridad, hay que recordar que el artículo 4.1.b) de la LRBRL, atribuye en su calidad de Administraciones públicas de carácter territorial, y dentro de la esfera de sus competencias, a los Municipios, las Provincias y las Islas «Las potestades tributaria y financiera» Como vemos, la propia LRBRL distingue ente la potestad financiera y la potestad tributaria, añadiendo el apartado 2 de dicho artículo 4 de la LRBRL, lo siguiente: «Lo dispuesto en el número precedente podrá ser de aplicación a las Entidades territoriales de ámbito inferior al municipal y, asimismo, a las Comarcas, Áreas Metropolitanas y demás Entidades locales, debiendo las Leyes de las Comunidades Autónomas concretar cuáles de aquellas potestades serán de aplicación.» Como se puede apreciar, no aparece el consorcio, salvo que consideremos que el consorcio se puede incluir dentro de la expresión «demás Entidades locales», extremo este que, como hemos dicho reiteradamente, no consideramos conforme al contenido expreso de la LRBRL.

Ahondando en la «potestad tributaria» y a sabiendas de que puede resultar reiterativo debemos afirmar, según nuestro criterio, que sólo lo Municipios, las Provincias y las Islas gozan siempre de ella, por ser Administraciones

26 JIMÉNEZ COMPAIRED (2009): 360.

27 MÉNDEZ LIMA (1998): 171.

REALA, n 4, julio-diciembre 2015, ISSN: 1989-8975 - DOI: http://dx.doi.org/10.24965/reala.v0i4.10302 
públicas de carácter territorial; mientras que las Entidades territoriales de ámbito inferior al municipal y, asimismo, a las Comarcas, Áreas Metropolitanas y demás Entidades locales, sólo y exclusivamente gozan de ella, cuando las leyes de las Comunidades Autónomas así lo establezcan expresamente. Pues bien, para que el consorcio pudiera gozar de potestad tributaria deberían de darse dos circunstancias de manera simultánea y obligatoria: primera, que una Comunidad Autónoma otorgue al consorcio la Consideración de Entidad local, y consideremos que se encuentra comprendido dentro de la expresión «demás Entidades locales»; y segunda, que la legislación de régimen local, de dicha Comunidad Autónoma, otorgue expresamente al consorcio la potestad tributaria.

Antes de proseguir conviene reseñar que, la Agencia Vasca de Protección de Datos, en su Informe CN13-054, de 21 de enero de 2014, reconoce la potestad tributaria de los consorcios, con base en la Norma Foral 3/1995, de 30 de marzo, reguladora de las Entidades de Ámbito Supramunicipal de Vizcaya. No obstante, como más adelante expondremos, consideramos que dicha potestad se encuentra vinculada más con la posibilidad de percibir tasas establecidas por los municipios que forman parte del consorcio, que con la posibilidad de establecer dichas tasas.

Como se ha referenciado con anterioridad, sólo la legislación autonómica de Andalucía, Galicia e Islas Baleares, confieren al consorcio la cualidad de Entidad local, por lo que deberemos examinar si dicha legislación autonómica confiere potestad tributaria al consorcio:

a) Andalucía: La Ley 5/2010, de 11 de junio, de autonomía local de Andalucía, establece en su artículo 78.4 lo siguiente: «Las potestades de los consorcios serán las estrictamente necesarias para el cumplimiento de sus fines, debiéndose contener de forma expresa en sus estatutos.» Como se puede apreciar, no se concreta de manera expresa la potestad tributaria, lo que podría vulnerar el contenido del artículo 4.2 de la LRBRL, al exigir que «debiendo las Leyes de las Comunidades Autónomas concretar cuáles de aquellas potestades serán de aplicación.» Más adelante, en su artículo 86.1 enumera los recursos de las haciendas de las entidades locales de cooperación, estableciendo lo siguiente: «La hacienda de las entidades locales de cooperación territorial estará integrada por los siguientes ingresos: b) Tasas, contribuciones especiales y precios públicos de los servicios y actividades atribuidos, de conformidad con lo previsto en la normativa reguladora de las haciendas locales.» Como se aprecia, dicho artículo efectúa una remisión a la legislación reguladora de las haciendas locales, en relación con la potestad tributaria de las entidades locales de cooperación - donde incluye a los consorcios-, por lo que dicha potestad tributaria, debería entenderse predicable, sólo para el caso de que el TRLRHL se la confiera, cosa que no sucede en el caso del consorcio.

a) Galicia: La Ley 5/1997, de 22 de julio, de Administración Local de Galicia, señala en su artículo 6.2 lo siguiente: «Las potestades y prerrogativas determinadas por el apartado anterior serán también de aplicación a las demás Entidades Locales no territoriales, de conformidad, en su caso, con lo establecido por sus estatutos, con las siguientes particularidades: a) La potestad tributaria se referirá, exclusivamente, al establecimiento de tasas, contribuciones especiales y precios públicos.» Como denota el contenido de dicho artículo, el consorcio sólo gozará de potestad tributaria, cuando así lo prevea expresamente sus estatutos y sólo referida al establecimiento de tasas, contribuciones especiales y precios públicos.

a) Islas Baleares: La Ley 20/2006, de 15 de diciembre, municipal y de régimen local de las Illes Balears, dispone en su artículo 45 que: «Los consorcios locales gozan de la naturaleza de ente local (...) La potestad tributaria se concreta en el establecimiento de tasas por prestación de servicios o realización de actividades y la imposición de contribuciones especiales. Asimismo, pueden fijar precios públicos y tarifas.» En este caso, la normativa de régimen local de Baleares, de manera específica le otorga potestad tributaria al consorcio.

Entendemos que, el resto de legislación autonómica de régimen local, al no reconocer expresamente la cualidad de Entidad local al consorcio, no puede conferirle potestad tributaria alguna, pues si lo hiciera, podría vulnerar el artículo 4.2 de la LRBRL. En este sentido, PERIS GARCÍA y LOPAZ PÉREZ ${ }^{28}$ afirman que la no inclusión de los consorcios en el art. 3.2 de la LRBRL, ha sido considerada por parte de la doctrina como motivo suficiente para negar el carácter de entidad local a los consorcios «negativa que por otra parte conlleva la negativa de dotarlos de cuantas potestades de las previstas en el artículo 4 se reconocen tanto a las entidades locales básicas como a las entidades locales en general según sus propias normas de creación», entre otras, las potestades financieras y tributarias.

Dicho lo anterior, y compartiendo lo dicho por TOSCANO GIL29, podemos decir que los artículos 150 a 152 del Capítulo I del Título IV del TRLRHL, desarrollan las normas comunes de los recursos de las entidades supramunicipales. Por lo que el citado Capítulo I, debe ser el marco legal donde encajar los posibles recursos

28 PERIS GARCÍA y LOPAZ PÉREZ (2010): 25.

29 TOSCANO GIL (2011): 98. 
tributarios de los consorcios. Bien entendido que dicho capítulo sólo es aplicable al consorcio, en la medida de que dicho consorcio sea considerado como Entidad local — lo que requiere su expresa regulación por el legislador autonómico—, y que además, el consorcio sea considerado como una entidad supramunicipal —lo que no siempre resulta así, pues existe la posibilidad de consorcios de ámbito no supramunicipal—.

Expuesto todo lo anterior, con carácter general, debemos abordar si realmente los consorcios tienen potestades para establecer y exigir tributos, o por contrario no tienen dicha potestad. Desde este momento, debemos avanzar que nuestra posición es contraria a reconocer potestades tributarias al consorcio, sabiendo que dicha posición es contraria a la mayoría de la doctrina científica, y sobre todo, a la posición mayoritaria de la doctrina jurídica. Dicha posición es adoptada a la luz de la legislación vigente, especialmente la LRBRL y el TRLRHL, de manera especial a raíz de la entrada en vigor de la LRSAL. Ahondando en la doctrina que coincide con nuestra posición, podemos adelantar que MÁS RIGÓ ${ }^{30}$, con base a la Consulta de la Dirección General de Coordinación con las Haciendas Territoriales, de 20 de octubre de 1989, opina que del examen del TRLRHL se puede deducir que los consorcios no gozan de la potestad tributaria, aunque sí pueden fijar precios públicos; y que CASTILLO BLANCO ${ }^{31}$, entiende que las disposiciones del TRLRHL no les son aplicables a los consorcios al negar el carácter de entidad local de los mismos. Argumento que debe ser obviado, según BLASCO DELGADO ${ }^{32}$ a firmando que: «el Consorcio es un Ente local público asociativo al que se atribuye potestad tributaria suficiente para establecer tanto contribuciones especiales como tasas, ...».

Por nuestra parte, entendemos que, si el legislador básico estatal hubiera querido otorgar potestades tributarias al consorcio, lo habría hecho, pues ha tenido muchas oportunidades para hacerlo, como ha sido la LRBRL y el TRLRHL, entre otras. Lo cierto, es que cuando el legislador básico estatal aprobó la LRBRL, decidió voluntariamente no conceder dichas potestades tributarias al consorcio. Debemos recordar, que borrador de anteproyecto de Ley básica del Gobierno y la administración local, de 22 de noviembre de 2005, establecía en su artículo 68, dedicado a los consorcios, lo siguiente: «2. Los consorcios tendrán personalidad jurídica propia, y sus estatutos determinarán los fines de los mismos, así como las particularidades del régimen orgánico, funcional y financiero.

Asimismo, a través de sus estatutos, las entidades consorciadas podrán acordar que el consorcio ostente la potestad tributaria para establecer, ordenar y exigir contribuciones especiales, tasas y precios públicos por los servicios que preste». En versiones posteriores de este mismo anteproyecto de Ley (artículo 78.2, de la versión de 5 de marzo de 2007; y artículo 80.2, de la versión de 5 de febrero de 2007), se suprimió el ultimo inciso de este apartado 2, a partir de «Asimismo, a través de sus estatutos, ... ».

Esta opinión, de que si el legislador básico estatal hubiera querido otorgar potestades tributarias al consorcio, lo habría hecho, se ve más reforzada, aún si cabe, si tenemos en cuenta que la Base 21.1.5, de la Ley 41/1975, de 19 de noviembre, de Bases del Estatuto de Régimen Local, establecía que: «Las Mancomunidades, Agrupaciones y consorcios estarán facultados para establecer tasas y contribuciones especiales por... » y el legislador cuanto derogó dicha Ley, con el nuevo texto de régimen local, no recogió disposición similar alguna. Pero también es cierto, que esta opinión se ve debilitada por el contenido del artículo 155.1 del Decreto de 17 de junio de 1955 por el que se aprueba el Reglamento de Servicios de las Corporaciones locales, al expresar que: «En los servicios prestados directamente por la Corporación, con o sin órgano especial de administración o mediante fundación pública del servicio, o indirectamente por concesión otorgada a particular o Empresa mixta, o por Consorcio con otros Entes públicos, las tarifas que hayan de satisfacer los usuarios tendrán la naturaleza de tasa y serán exaccionables por la vía de apremio. » Del contenido de dicho artículo, parece desprenderse que, en los servicios prestados por los consorcios, las tarifas que hayan de satisfacer los usuarios, tendrán la naturaleza de tasa (tributo), pero no parece desprenderse, de manera tan meridiana, que dicha tasa pueda ser establecida directamente por el consorcio. El citado el Reglamento de Servicios de las Corporaciones locales no está formalmente derogado, por lo que sus disposiciones son de aplicación, siempre y cuando, no hayan sido derogadas expresa o tácitamente por normas posteriores, tal y como señaló en su día, la Sentencia del Tribunal Supremo de 18 de marzo de 1993 (recurso 6439/1990).

En el presente supuesto, consideramos que la interpretación que hacen algunos tribunales sobre la potestad tributaria de los consorcios no puede apartarse de la voluntad expresada por el legislador en la Ley. La interpretación de la Ley nunca puede suplir la voluntad del legislador, es decir, no puede ser tan amplia como para ir en contra de la propia voluntad del legislador, que se supone expresada en el mismo texto; y que se presume que lo que el legislador ha querido establecer, se corresponde fielmente con los términos o expresiones de la Ley. Hay una coincidencia entre la razón de la Ley y la voluntad del legislador.

\footnotetext{
30 MAS RIGO (2003): 26-27.

31 CASTILLO BLANCO (1991): 413-414.

32 BLASCO DELGADO (2009): 21 y 25.
}

REALA, n 4, julio-diciembre 2015, ISSN: 1989-8975 - DOI: http://dx.doi.org/10.24965/reala.v0i4.10302 
Antes de analizar cada una de las figuras impositivas, conviene señalar que el sistema tributario de las Entidades locales, hoy en día recogido en el TRLRHL y anteriormente en la LHL de 1988, diseña un modelo basado en impuestos de exacción obligatoria, impuestos de exacción potestativa o voluntaria, contribuciones especiales y, sobre todo, en las tasas por prestación de servicios o por el aprovechamiento especial del dominio público local.

Hay que recordar que, la potestad reglamentaria — que no legislativa— en materia de tributos de las Entidades locales, se manifiesta a través de las ordenanzas fiscales de cada Entidad local. Así, para poder establecer y exigir un tributo local, la entidad local debe contar previamente con potestad reglamentaria, pues de conformidad con lo establecido en el artículo 15.1 del TRLHL, dicho tributo sólo puede establecerse y exigirse mediante la previa aprobación de una ordenanza fiscal que acuerde su imposición, excepción hecha de los supuestos previstos en el artículo 59.1 (IBI, IAE, e IVTM). Los municipios, las provincias y las islas, en su calidad de Administraciones públicas de carácter territorial, y dentro de la esfera de sus competencias, gozan de la potestad reglamentaria; mientras que el resto de las Entidades locales, sólo gozarán de aquellas potestades que les confieran las leyes de las comunidades autónomas. Además, el artículo 12.2 del TRLRHL, indica que: «A través de sus ordenanzas fiscales las entidades locales podrán adaptar la normativa a que se refiere el apartado anterior al régimen de organización y funcionamiento interno propio de cada una de ellas, sin que tal adaptación pueda contravenir el contenido material de dicha normativa.» Esta prohibición de que la normativa reglamentaria local, pueda contradecir la LGT, el TRLRHL, y las disposiciones dictadas para su desarrollo, nos lleva a cuestionar, si los estatutos de un consorcio, pueden contravenir el contenido material de dichas normas legales.

A la vista de lo anterior, entendemos que son las leyes de las comunidades autónomas las que, de manera expresa, deben conceder la potestad reglamentaria a las entidades locales contempladas en el artículo 4.2 de la LRBRL, y no los estatutos de dicha entidad. En relación con el ejercicio de la potestad reglamentaria, en las ordenanzas fiscales establecidas por las asambleas de los consorcios, NIETO GARRIDO ${ }^{33}$, afirma que dicha potestad reglamentaria: «responde, directa o indirectamente, como la Ley, al principio democrático de representación popular. Y, como la Ley, sirven para hacer efectivo el principio de autoimposición, según el cual los tributos han de ser establecidos y aprobados por los representantes de aquellos que están llamados a soportarlos. Un principio que no se cumple con una Ordenanza aprobada por la Asamblea consorcial, sobre todo, teniendo en cuenta la posible integración en el Consorcio de entidades privadas sin ánimo de lucro (art. 87 LBRL).».

Al igual que ocurre con la potestad tributaria, la Ley 5/2010, de 11 de junio, de autonomía local de Andalucía, no otorga expresamente la potestad reglamentaria a los consorcios, remitiéndose al contenido de los estatutos de dichos consorcios; la Ley 5/1997, de 22 de julio, de Administración Local de Galicia, igualmente remite al contenido de los estatutos; y la Ley 20/2006, de 15 de diciembre, municipal y de régimen local de las Illes Balears, señala que los consorcios están dotados de todas las potestades previstas en la legislación básica de régimen local. A nuestro entender, el contenido de estas leyes vulnera el contenido del artículo 4.2 de la LRBRL, al exigir que «debiendo las Leyes de las Comunidades Autónomas concretar cuáles de aquellas potestades serán de aplicación.» En definitiva, entendemos que la potestad reglamentaria, al igual que ocurre con la potestad tributaria, debe concretarse de manera expresa en las leyes de las Comunidades Autónomas, que regulan la figura de los consorcios.

\subsection{Impuestos}

La LGT define a los impuestos en su artículo 2.2.c) como: «los tributos exigidos sin contraprestación cuyo hecho imponible está constituido por negocios, actos o hechos que ponen de manifiesto la capacidad económica del contribuyente.».

En el ámbito de las haciendas locales, la figura del impuesto queda reservada en exclusiva para los Ayuntamientos. Así, el artículo 59 del TRLRH, sólo faculta a los ayuntamientos a establecer y exigir impuestos. Con carácter obligatorio —es decir, todos los ayuntamientos—, el Impuesto sobre Bienes Inmuebles; el Impuesto sobre Actividades Económicas; y el Impuesto sobre Vehículos de Tracción Mecánica. Y con carácter potestativo —es decir, si así lo decide el ayuntamiento-, el Impuesto sobre Construcciones, Instalaciones y Obras y el Impuesto sobre el Incremento de Valor de los Terrenos de Naturaleza Urbana. Tanto la exacción obligatoria, como el establecimiento y exacción potestativa, deberán realizarse de acuerdo con lo establecido en el TRLRHL, las disposiciones que la desarrollan, y las respectivas ordenanzas fiscales. Del contenido del artículo 59 del TRLRH se desprende que los consorcios no podrán establecer impuestos.

De igual manera, los consorcios no podrán establecer recargos sobre los impuestos municipales, pues los únicos recargos sobre los impuestos municipales que contempla el TRLRHL, son: a) El recargo de las provincias sobre el Impuesto sobre Actividades Económicas, contemplado en el artículo 134 del TRLRHL. También exigible

33 NIETO GARRIDO (1997): 186-187.

REALA, n 4, julio-diciembre 2015, ISSN: 1989-8975 - DOI: http://dx.doi.org/10.24965/reala.v0i4.10302 
por los consejos insulares de las Illes Balears, tal y como señala el artículo 157 del TRLRHL y por los cabildos insulares de Canarias, tal y como dispone el artículo 158 del TRLRHL; y b) El recargo de las Áreas metropolitanas sobre el Impuesto sobre Bienes Inmuebles sitos en el territorio de la entidad, contemplado en el artículo 153.1.a) de TRLRHL.

\subsection{Tasas}

La LGT define a las tasas en su artículo 2.2.a) como «los tributos cuyo hecho imponible consiste en la utilización privativa o el aprovechamiento especial del dominio público, la prestación de servicios o la realización de actividades en régimen de derecho público que se refieran, afecten o beneficien de modo particular al obligado tributario, cuando los servicios o actividades no sean de solicitud o recepción voluntaria para los obligados tributarios o no se presten o realicen por el sector privado.» Hasta su supresión por Disposición final 58 de la Ley 2/2011, de 4 de marzo, además contemplaba que «Se entenderá que los servicios se prestan o las actividades se realizan en régimen de derecho público cuando se lleven a cabo mediante cualquiera de las formas previstas en la legislación administrativa para la gestión del servicio público y su titularidad corresponda a un ente público.» En este sentido, la DGT en su Informe de 26 de julio de 2011, indica que «La supresión del segundo párrafo del artículo 2.2.a) de la LGT ha supuesto la vuelta a un esquema similar al anterior establecido por el Tribunal Supremo (...) que estableció un criterio diferenciador para distinguir entre tasa y tarifa en relación con los servicios públicos locales en base a la condición del gestor de los mismos».

Señala el artículo 21.1 del TRLRHL que «Las entidades locales, en los términos previstos en esta ley, podrán establecer tasas por la utilización privativa o el aprovechamiento especial del dominio público local, así como por la prestación de servicios públicos o la realización de actividades administrativas de competencia local que se refieran, afecten o beneficien de modo particular a los sujetos pasivos.» Añadiendo que en todo caso tendrán la consideración de tasa: «B) La prestación de un servicio público o la realización de una actividad administrativa en régimen de derecho público de competencia local que se refiera, afecte o beneficie de modo particular al sujeto pasivo, cuando... : b) Que no se presten o realicen por el sector privado, esté o no establecida su reserva a favor del sector público conforme a la normativa vigente.» Como se puede ver, el TRLRHL y la LGT difieren levemente.

El establecimiento de este tributo por los consorcios es el que mayor controversia suscita. A la vista del contenido del artículo 20 del TRLRHL, cabe analizar si los consorcios pueden establecer tasas por la utilización privativa o el aprovechamiento especial del dominio público local, y si estas mismas entidades pueden establecer tasas por la prestación de servicios públicos o la realización de actividades administrativas de competencia local, por lo que resulta oportuno analizar qué tipo de entidades locales pueden establecer tasas. En este sentido, el artículo 57.1 del TRLRHL, establece que «Los ayuntamientos podrán establecer y exigir tasas por la prestación de servicios o la realización de actividades de su competencia y por la utilización privativa o el aprovechamiento especial de los bienes del dominio público municipal...»; el artículo 132.1 del TRLRHL, establece que: «Las Diputaciones Provinciales podrán establecer y exigir tasas por la prestación de servicios o la realización de actividades de su competencia, y por la utilización privativa o el aprovechamiento especial de bienes del dominio público provincial ... »; y el artículo 152.1 del TRLRHL, establece que: «Las comarcas, áreas metropolitanas, entidades municipales asociativas y demás entidades supramunicipales podrán establecer y exigir tasas (...) de conformidad con lo previsto en sus respectivas normas de creación y en los términos establecidos en esta ley y disposiciones que la desarrollen.»Como se puede apreciar, los Ayuntamientos, Diputaciones provinciales, Comarcas, Áreas metropolitanas, entidades municipales asociativas y demás entidades supramunicipales podrán establecer y exigir tasas. Por el contrario, nada dice el TRLRHL sobre la posibilidad de que los consorcios puedan establecer y exigir tasas. Si bien, podría considerarse el consorcio incluido dentro de las entidades supramunicipales, siempre y cuando la legislación autonómica los considerara como Entidad local y tuvieran un ámbito supramunicipal. Condiciones que no siempre se cumplen.

De este modo, la contestación de la Dirección General de coordinación con las Haciendas Territoriales, de 20 de octubre de 1989, a una cuestión tributaria, señalo lo siguiente: «Los consorcios de aparición posterior a la Ley 7/1985 no podrán proceder en ningún caso al establecimiento o exacción de tasas por la prestación de los servicios de su competencia. Todo lo anterior queda, además, confirmado por la propia Ley 39/1988, de cuyo art. 48 se desprende claramente que los consorcios (excepción hecha de los que hubieran sido creados con anterioridad a la entrada en vigor de la Ley 7/1985) no tienen la condición de Entidades locales, pues de tenerla, la propia Ley habilitaría a los consorcios para el establecimiento y cobranza de precios públicos mientras que, por el contrario, el apartado 2 del expresado artículo faculta a las Entidades Locales para autorizar a los consorcios la fijación del importe de dichos precios pero no el establecimiento de los mismos, lógica consecuencia de la naturaleza de ingresos públicos integrados en el marco de las Haciendas Locales que lo caracteriza impidiendo su creación ex novo al margen de dichas Haciendas.». 
Se debe poner de manifiesto que la Dirección General de coordinación con las Haciendas Territoriales, dependiente de la Subsecretaria de presupuesto y gasto público del Ministerio de Hacienda, constituía el centro directivo al que correspondía ejercer las funciones legalmente atribuidas al Ministerio de Hacienda en materia de régimen financiero de las Corporaciones locales, de conformidad con el Real Decreto 1874/1981, de 3 de agosto, por el que se reestructura la Dirección General de Coordinación con las Haciendas Territoriales. Y también debemos poner de manifiesto que en virtud del artículo 18.1 de a LGT de 1963, vigente en esos momentos, la facultad de dictar disposiciones interpretativas o aclaratorias de las leyes y demás disposiciones en materia tributaria corresponden privativamente al Ministro de Hacienda, siendo las mismas de obligado acatamiento para los órganos de gestión de la Administración pública.

De la lectura de la contestación de la Dirección General de coordinación con las Haciendas Territoriales, de 20 de octubre de 1989, parece desprenderse que los consorcios no pueden establecer tasas, sin perjuicio que puedan percibir las tasas establecidas por los municipios que forman parte del consorcio. A este respecto, la Norma Foral 11/1989, de 5 de julio, reguladora de las Haciendas Locales de Guipúzcoa, establece en su artículo 57.3 lo siguiente: «Los Municipios, las Mancomunidades y demás Entidades Municipales asociativas, podrán delegar en los consorcios que hubieran constituido mediante las fórmulas de colaboración que procedan, las facultades de gestión, liquidación y recaudación de las tasas que aquéllos establezcan por la prestación de los servicios asumidos por el consorcio.» Idéntica redacción encontramos en el artículo 57.3 de la Norma Foral 41/1989, de 19 de julio, reguladora de las Haciendas Locales de Álava. Y, similar redacción encontramos en el artículo 59.3 de la Norma Foral, de 16 de diciembre, de Haciendas Locales de Vizcaya. No debemos olvidar que las Normas Forales reseñadas adaptan la legislación estatal sobre haciendas locales, a las peculiaridades de los Territorios Históricos del País Vasco.

En materia de ingresos de derecho público, de manera especial en los ingresos de naturaleza tributaria, rige el principio de reserva de Ley. Las tasas, recordemos, es una de las tres clases de tributos contemplados en el artículo 2.2.a) de la LGT. Esta reserva de Ley viene establecida de manera directa en el artículo 31.3 de la Constitución al exigir que «sólo podrán establecerse prestaciones personales o patrimoniales de carácter público con arreglo a la ley», y se concreta en materia tributaria en los en los apartados del 1 al 3 del artículo 133 del texto constitucional. En particular, el artículo 133.2 de la Constitución, señala que «Las Comunidades Autónomas y las Corporaciones locales podrán establecer y exigir tributos de acuerdo con la Constitución y las leyes.».

En definitiva, consideramos que, el hecho de que un consorcio establezca una tasa, cuando dicha posibilidad no se encuentra recogida expresamente en el TRLRHL —a diferencia de lo que ocurre los Ayuntamientos, Diputaciones provinciales, Comarcas, Áreas metropolitanas, entidades municipales asociativas y demás entidades supramunicipales-, podría suponer una infracción al principio de reserva de Ley contemplado en el artículo 133.2 de la Constitución, puesto en relación con el contenido del artículo 20.1 del TRLRHL, que exige que las tasas se establezcan en los términos previsto en dicha Ley.

Junto a la aparente imposibilidad — fundamentada en el principio de reserva de Ley- de que los consorcios puedan establecer tasas, cabría preguntarse si se puede realizar una interpretación analógica, y por tanto considerar que los consorcios si pueden establecer tasas. Para dilucidar dicha cuestión, debemos partir del hecho de que el TRLRHL, al definir el hecho imponible de las tasas, utiliza la expresión genérica «Las entidades locales, en los términos previstos en esta ley, podrán establecer tasas», por tanto, debemos decantarnos por que dicha posibilidad se encuentra vedada, pues el TRLRHL remarca, al definir el hecho imponible de las tasas, que el establecimiento de tasas, por las entidades locales se realizará «en los términos previstos en esta ley» y dicha ley no hace referencia alguna a los consorcios a diferencia de lo que ocurre con los Ayuntamientos, Diputaciones provinciales, Comarcas, Áreas metropolitanas, entidades municipales asociativas y demás entidades supramunicipales. Pero es que, además, la LGT, de aplicación en la exacción de los tributos locales por expresa disposición de los artículos 12 del TRLRHL y 1.1 de la LGT, establece en su artículo 14, lo siguiente: «No se admitirá la analogía para extender más allá de sus términos estrictos el ámbito del hecho imponible, ... » y en su artículo 20 define el hecho imponible como «el presupuesto fijado por la ley para configurar cada tributo».

Tal y como señala VILLAR EZCURRA ${ }^{34}$, la prohibición de la analogía para extender más allá de sus términos estrictos el ámbito del hecho imponible, excluye «la aplicación analógica a situaciones de hecho no amparadas por el principio de reserva de ley, que cubre no sólo el aspecto material del hecho imponible sino también su ámbito temporal, espacial, subjetivo y cuantitativo.» Este rechazo a la aplicación de la analogía ha estado íntimamente ligado, tal y como señalan CASADO OLLERO, LOZANO SERRANO, MARTíN QUERALT y TEJERIZO LÓPEZ35, a la

34 VILLAR EZCURRA (2010): 479-480.

35 CASADO OLLERO, LOZANO SERRANO, MARTÍN QUERALT, JTEJERIZO LÓPEZ (2008): 193. 
«concepción positivista y garantista del Derecho Tributario.» Para SÁINZ DE BUJANDA ${ }^{36}$, la prohibición de la analogía en la LGT se ha fundado, por lo general, en la doctrina, en «el principio de reserva de ley tributaria» En este mismo sentido, CALVO ORTEGA ${ }^{37}$, afirma que: «la interpretación analógica como actividad parcialmente creativa es contraria al principio de reserva de ley».

Vista la legislación vigente y los posicionamientos doctrinales, antes reseñados, podría decirse que, al no contemplar expresamente el TRLRHL la posibilidad de que los consorcios establezcan tasas, el establecimiento de las mismas, por los citados entes, aparentemente supondría una interpretación analógica del hecho imponible, prohibida por nuestro ordenamiento jurídico.

Dicho lo anterior, lo cierto es que los Tribunales se han pronunciado a favor de la potestad de establecer tasas por los consorcios. Sirva de ejemplo la Sentencia del Tribunal Supremo, de 31 de mayo de 2010 (recurso 6361/2005) en la que se dice de manera literal lo siguiente: «... una vez ejercida la potestad normativa en materia tributaria que al consorcio reconocen los artículos 106.2 de la Ley de Bases de Régimen Local y 12.2 de la Ley Reguladora de las Haciendas Locales,... » Añadiendo más adelante que: «La conclusión a que llega la Sala no supone desconocer la potestad tributaria al consorcio de Aguas para imponer y regular las tasas que puede percibir por la prestación de los servicios cuya gestión tiene encomendada, ...».

El Juzgado de lo Contencioso Administrativo n. ${ }^{\circ} 6$ de Valencia, en su Sentencia de 29 de noviembre de 2011, reconoce la potestad tributaria de un consorcio, utilizando como fundamento el contenido del artículo 87 de la $\mathrm{LRBRL}^{38}$. Pero dicho artículo sólo hace referencia a la posibilidad de que las Entidades locales puedan constituir consorcios con otras Administraciones públicas, pero nada dice de que dichos consorcios cuenten con potestad tributaria.

\subsection{Contribuciones Especiales}

La LGT define a las contribuciones especiales en su artículo 2.2.b) como: «los tributos cuyo hecho imponible consiste en la obtención por el obligado tributario de un beneficio o de un aumento de valor de sus bienes como consecuencia de la realización de obras públicas o del establecimiento o ampliación de servicios públicos.».

De una parte, el artículo 28 del TRLRHL, que: «Constituye el hecho imponible de las contribuciones especiales la obtención por el sujeto pasivo de un beneficio o de un aumento de valor de sus bienes como consecuencia de la realización de obras públicas o del establecimiento o ampliación de servicios públicos, de carácter local, por las entidades respectivas.» De otra, el artículo 29.1 del TRLRHL, señala lo siguiente: «Tendrán la consideración de obras y servicios locales: a) Los que realicen las entidades locales dentro del ámbito de sus competencias...; b) Los que realicen dichas entidades por haberles sido atribuidos o delegados por otras entidades públicas y aquellos cuya titularidad hayan asumido de acuerdo con la ley; c) Los que realicen otras entidades públicas, o los concesionarios de estos, con aportaciones económicas de la entidad local.» Como se puede apreciar, el TRLRHL, en relación con las contribuciones especiales utiliza la expresión «entidades respectivas» a diferencia de lo que sucede con las tasas que utiliza a expresión «Entidades locales», además considera obras y servicios públicos locales los que realicen «otras entidades públicas».

A la vista de lo establecido en los artículos 28 y 29 del TRLRHL, aparentemente, nada impide que los consorcios puedan establecer contribuciones especiales, cuando realicen obras y presten servicios locales. Todo ello sin perjuicio de lo que diremos a continuación.

Una de las figuras típicas en los consorcios, son los denominados consorcios urbanísticos, por ello consideramos de interés analizar el contenido del Real Decreto 3288/1978, de 25 de agosto, por el que se aprueba el Reglamento de Gestión Urbanística para el desarrollo y aplicación de la Ley sobre Régimen del Suelo y Ordenación Urbana, vigente en la actualidad. Eso, sin perder de vista que estamos en presencia de una norma reglamentaria y que dichos consorcios, constituyen una categoría especial dentro de los consorcios.

El Real Decreto 3288/1978, de 25 de agosto, en su artículo 7.3 señala que, los Ayuntamientos «Para el desarrollo de actividades de interés para su población, y que no sean de su competencia exclusiva, podrán constituir consorcios con Entidades de diferente orden o naturaleza.» En su artículo 14.3, indica que «En ningún caso podrá delegarse en el consorcio la potestad de establecer tributos, pero sí se le podrá encomendar la recaudación unificada de aquellos que graven el suelo o su aprovechamiento, pudiendo en este caso recurrir a la vía de apremio.» Y en su artículo 11.1, establece que «Las Mancomunidades o Agrupaciones urbanísticas podrán acordar, previos los trámites establecidos en su ordenamiento peculiar, la imposición de tasas y contribuciones especiales previstas en la legislación local, cuando establezcan servicios o realicen obras que legitime dicha imposición.» Como se puede

36 SÁINZ DE BUJANDA (1993): 72.

37 CALVO ORTEGA (2005): 125.

38 Se deroga, con efectos de 2 de octubre de 2016, por la disposición derogatoria única.a) de la Ley 40/2015. 
apreciar, este Real Decreto, confiere la posibilidad a los Ayuntamientos de constituir consorcios urbanísticos, prohibiendo expresamente que se delegue en los mismos la potestad de establecer tributos — básicamente tasas y contribuciones especiales-, mientras que a las Mancomunidades o Agrupaciones urbanísticas, previos los trámites establecidos en su ordenamiento peculiar, les confiera la potestad de establecer la imposición de tasas y contribuciones especiales previstas en la legislación local. En definitiva, una vez más, la normativa estatal veda a los consorcios la potestad de establecer las tasas y contribuciones especiales previstas en la legislación local.

\subsection{Precios Públicos}

Es notorio que los precios públicos no son tributos, al no estar contemplados dentro las clases de tributos contemplados en el artículo 2.2 de la LGT. De manera evidente, tampoco el TRLRHL, incluye a los precios públicos dentro de los tributos que pueden exigir las Entidades locales, no obstante, hemos considerado oportuno incluir un apartado sobre los mismos, pues entendemos que ayudan a clarificar la potestad tributaria de los consorcios.

La Ley 8/1989, de 13 de abril, de Tasas y Precios Públicos, modificada por la Ley 5/1998, de 13 de julio, de modificación del Régimen Legal de las Tasas Estatales y Locales y de Reordenación de las Prestaciones Patrimoniales de Carácter Público, consecuencia de la Sentencia del Tribunal Constitucional 185/1995, de 14 de diciembre, regula con carácter general los precios públicos, si bien en el ámbito de las haciendas locales cuentan con una regulación específica dentro del TRLRHL.

El vigente artículo 24 de la Ley 8/1989, de 13 de abril, define los precios públicos de la siguiente manera: «Tendrán la consideración de precios públicos las contraprestaciones pecuniarias que se satisfagan por la prestación de servicios o la realización de actividades efectuadas en régimen de Derecho público cuando, prestándose también tales servicios o actividades por el sector privado, sean de solicitud voluntaria por parte de los administrados.».

El artículo 41 del TRLRHL, cuando define el concepto de precio público, indica que: «Las entidades locales podrán establecer precios públicos por la prestación de servicios o la realización de actividades de la competencia de la entidad local, siempre que no concurra ninguna de las circunstancias especificadas en el artículo 20.1.B) de esta ley.» En este sentido, el 127 del TRLRHL, establece que: « Los ayuntamientos podrán establecer y exigir precios públicos por la prestación de servicios o la realización de actividades de competencia municipal,...»; el artículo 148 del TRLRHL, establece que: «Las Diputaciones Provinciales podrán establecer y exigir precios públicos por la prestación de servicios o la realización de actividades de su competencia, ... »; y el artículo 152.1 del TRLRHL, establece que: «Las comarcas, áreas metropolitanas, entidades municipales asociativas y demás entidades supramunicipales podrán establecer y exigir (...) precios púbicos, de conformidad con lo previsto en sus respectivas normas de creación y en los términos establecidos en esta ley y disposiciones que la desarrollen.» Como se puede apreciar, los Ayuntamientos, Diputaciones provinciales, Comarcas, Áreas metropolitanas, entidades municipales asociativas y demás entidades supramunicipales podrán establecer y exigir precios públicos. Por el contrario, nada dice el TRLRHL sobre la posibilidad de que los consorcios puedan establecer y exigir precios públicos.

En relación con esta figura y por lo que aquí nos interesa, el artículo 47.2 del TRLRHL, señala en su primer inciso que: «Las entidades locales podrán atribuir a sus organismos autónomos la fijación de los precios públicos, por ella establecidos, correspondientes a los servicios a cargo de dichos organismos, salvo cuando los precios no cubran su coste. Tal atribución podrá hacerse, asimismo y en iguales términos, respecto de los consorcios, a menos que otra cosa se diga en sus estatutos.» Es decir, que no sean de solicitud o recepción voluntaria para los administrados y que no se presten o realicen por el sector privado, esté o no establecida su reserva a favor del sector público conforme a la normativa vigente.

Debemos hacer dos precisiones: La primera, que la atribución para la fijación —que no establecimiento o modificación - de precios públicos, en el caso de que sean varias las Entidades locales consorciadas, entendemos que deberá ser por conferida por todas y cada una de las citadas Entidades locales. La segunda, que como se ha dicho con anterioridad, la contestación de la Dirección General de coordinación con las Haciendas Territoriales, de 20 de octubre de 1989, establece que: «las Entidades Locales para autorizar a los consorcios la fijación del importe de dichos precios, pero no el establecimiento de los mismos».

Resulta de interés analizar la diferencia entre «establecer» $y$ «fijar». Entendemos que el término «establecer», habla de la potestad de la Entidad local de exigir el pago del precio público, mientras que el término «fijar», hace referencia a la potestad del consorcio para determinar la cuantía a satisfacer por el precio público, en función del coste del servicio prestado o la actividad realizada. El Diccionario de la RAE, define el término «establecer» como: fundar, instituir, ordenar, mandar, decretar; y define, el término «fijar» como: determinar, limitar, precisar, designar de un modo cierto. Aunque la verdad es, que la redacción de artículo 47 del TRLRHL, genera cierta confusión, por cuanto dicho artículo tiene como título el término «Fijación»; y en su apartado 1, habla de la potestad de establecer 
y modificar los precios públicos por el Pleno de la Corporación; y su apartado 2, habla de la posibilidad de atribuir a los consorcios la fijación de los precios públicos.

Según ALONSO HIGUERA ${ }^{39}$, los precios públicos son: «ingresos financieros de los Entes locales, que el artículo 2.1.e) incluye en la enumeración de los recursos de la hacienda de las entidades locales» Esta consideración del precio público como ingreso financiero, de naturaleza no tributaria, guardaría relación con el contenido del artículo 6.5 de la LRJAPyPAC, relativa a los convenios de colaboración, que señala en su segundo inciso que los estatutos del consorcio determinarán las particularidades de su régimen financiero.

\section{CONCLUSIONES}

La figura del consorcio local y su consideración como Entidad local, ha sido un tema sujeto a constante discusión doctrinal y jurídica, tras la entrada en vigor de la LRBRL. Esta discusión se ha acrecentado aún más, si cabe, desde la entrada en vigor de la LRSAL, al establecer de manera obligatoria la adscripción de los consorcios a una de las Entidades locales asociadas para la constitución de dicho consorcio. Los pronunciamientos jurisdiccionales, en su mayoría, se posicionan en favor de considerar que el hecho de que los consorcios no vengan incluidos como entidades locales en el artículo 3 de la LRBRL, no impide la caracterización como ente local del consorcio, ya que la enumeración que verifica el apartado segundo de este precepto no tiene carácter exclusivo. Este posicionamiento mayoritario, tiene sus excepciones en las Sentencias de 15 de septiembre de 2011 del Tribunal Supremo y de 15 de octubre de 2009 de la Audiencia Nacional.

La problemática de los consorcios se acrecienta cuando se trata de otorgar potestades —en particular la tributaria-, a dichos entes, que el ordenamiento jurídico sólo contempla, con carácter general, respecto a las Entidades locales de primer grado (municipios, provincias e islas) y, con ciertas limitaciones a las entidades locales de segundo grado (entidades territoriales de ámbito inferior al municipal, comarcas, áreas metropolitanas y demás entidades locales).

Si bien las Entidades locales pueden establecer tasas — por la utilización privativa o el aprovechamiento especial del dominio público local, así como por la prestación de servicios públicos o la realización de actividades administrativas de competencia local一, dicho establecimiento será en los términos previstos en el TRLRHL, por expresa dicción del propio TRLRHL. Ningún artículo del TRLRHL faculta a los consorcios a establecer tasas. Por el contrario, dicha facultad, sí es contemplada de manera expresa en el TRLRHL para las Entidades locales citadas en el artículo 3 de la LRBRL. De la contestación de la Dirección General de coordinación con las Haciendas Territoriales, de 20 de octubre de 1989, parece desprenderse que los consorcios no pueden establecer tasas, sin perjuicio de que puedan percibir las tasas establecidas por los municipios que forman parte del consorcio. No obstante, los pronunciamientos jurisdiccionales, en su mayoría, se posicionan en favor de la potestad de establecer tasas por los consorcios.

A partir de la entrada en vigor de la LRSAL, la constitución de un consorcio por parte de las Entidades locales, solo podrá tener lugar cuando la cooperación no pueda formalizarse a través de un convenio y siempre que, en términos de eficiencia económica, aquélla permita una asignación más eficiente de los recursos económicos. Es decir, en términos de racionalización del gasto y de mejora de la gestión del sector público.

Puesto que la figura del consorcio se utiliza de manera habitual, para la prestación de un servicio de competencia local con carácter supramunicipal, y que la prestación de servicios públicos de carácter supramunicipal es una competencia propia de las Diputaciones provinciales, en virtud de lo establecido en el artículo 36.1.c) de la LRBRL, podría ser la Diputación provincial la que estableciera y exigiera los tributos (normalmente tasas) por la prestación de dichos servicios, y que el rendimiento obtenido por dichos tributos fuera transferido al consorcio, ya que la potestad tributaria no plantea duda alguna en el caso de las Diputaciones provinciales.

\section{BIBLIOGRAFÍA}

ALONSO HIGUERA, Carmen (2002): “Manual del Secretario", Tomo I, Ed. Atelier, págs. 973-977.

BLASCO DELGADO, Carolina: "La potestad tributaria de los consorcios locales en el establecimiento y exigencia de tasas", Revista General de Derecho Administrativo, n. ${ }^{\circ} 22$, págs. 1-34.

CALVO ORTEGA, Rafael (2005): Curso de Derecho Financiero. Tomo I. Derecho Tributario. Parte General, Ed. Aranzadi.

CASADO OLLERO, Gabriel; LOZANO SERRANO, Carmelo; MARTíN QUERALT, Juan; TEJERIZO LÓPEZ, José Manuel (2008): Curso de derecho financiero y tributario, 19. ${ }^{a}$ edición, Ed. Tecnos.

39 ALONSO HIGUERA (2002): 973. 
CASTILLO BLANCO, Federico (1991): "Los consorcios de entidades locales: Análisis y valoración a la luz de la nueva legislación de Régimen local”, Revista de administración pública, n. ํ124, págs. 397-416.

CASTILLO BLANCO, Federico (2014): "La nueva regulación de los consorcios públicos: interrogantes y respuestas sobre el régimen jurídico de su personal”, R.V.A.P. núm. especial 99-100. Mayo-Diciembre 2014, págs. 887-920.

COBO OLVERA, Tomás (2008): "El régimen jurídico de las administraciones públicas y el procedimiento administrativo común, El Consultor de los Ayuntamientos y Juzgados", Ed. La Ley.

CORCUERA TORRES, Amable (2005): "Estabilidad presupuestaria y Corporaciones Locales: Problemática Jurídica”, en Revista de Estudios Locales (Cunal), n. ${ }^{\circ}$ 83, págs. 29-32.

GARCIA RUBIO, Fernando (2014): "Las entidades supramunicipales en el gobierno local español. Reflexiones tras la reforma de la sostenibilidad”, en Cuadernos de Derecho Local, n. ${ }^{\circ} 34$, Fundación Democracia y Gobierno Local, págs. 162-195.

JIMÉNEZ ASENSIO, Rafael (2014a): “¿Réquiem por los consorcios? Notas sobre el nuevo régimen jurídico de los consorcios tras la LERSAL", en Blog de Estudio de Consultoría Sector Público SLU.

JIMÉNEZ ASENSIO, Rafael (2014b) “La reforma local”, Anuario Aragonés del Gobierno Local, n. 5, págs. 281-328.

JIMÉNEZ COMPAIRED, Ismael (2009): "Las competencias autonómicas sobre la Hacienda Local a la luz de la Sentencia del Tribunal Constitucional 31/2010, de 28 de junio", Anuario Aragonés del Gobierno Local, n. ${ }^{\circ} 1$, págs. 355-364.

MAS RIGO, Jeroni Miquel (2003): "Los consorcios locales. Una ojeada a la doctrina y a la jurisprudencia”, Revista de Estudios Locales, n. ${ }^{\circ} 68$, págs. 17-28.

MARTÍN MATEO, Ramón (1987): Entes locales complejos: mancomunidades, agrupaciones, consorcios, comarcas, áreas metropolitanas, Ed. Trivium.

MÉNDEZ LIMA, Jorge Luis (1998): “Los consorcios locales (el art. 87 de la ley reguladora de las bases de Régimen Local)", Anales de la Facultad de Derecho. Universidad de La Laguna, n. ${ }^{\circ}$ 15, págs. 153-174.

NIETO GARRIDO, Eva María (1997): El consorcio administrativo, Ed. Cedecs.

PÉREZ TORRENTE, José Antonio (1996): “Els consorcis", Autonomies. Revista catalana de derecho público, n. ${ }^{\circ} 21$, págs. 51-65.

PERIS GARCÍA, Pura y LOPAZ PÉREZ, Ana María (2010): “El Régimen local valenciano: primeras aproximaciones a la nueva Ley de Régimen Local”, Comunicación en la XXXVI Reunión de Estudios Regionales - AECR.

RIVERO YSERN, José Luis (1995): "Los consorcios locales. Evolución histórica”, en Jornadas de estudios sobre consorcios locales: temas de administración local, Ed. Adhara, págs. 115-150.

SÁINZ DE BUJANDA, Fernando (1993): Lecciones de Derecho Financiero, 10. ${ }^{a}$ edición, Facultad de Derecho de la Universidad Complutense.

SÁNCHEZ-OSTIZ, Pablo (2006): "Fundamentos metodológicos para el estudio de la parte especial del Derecho penal”, Materiales docentes, Universidad de Navarra, págs. 1-20.

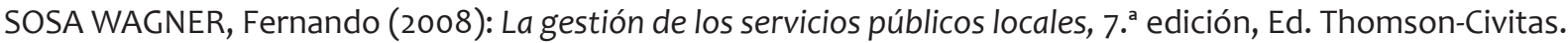

TOSCANO GIL, Francisco (2011): "Los consorcios Locales", en Los consorcios metropolitanos, Serie Claves del Gobierno Local, n. ${ }^{\circ}$ 13, Fundación Democracia y Gobierno Local, págs. 29-102.

TOSCANO GIL, Francisco (2015): "El consorcio administrativo en la encrucijada”, Revista de Estudios de la Administración Local y Autonómica. Nueva Época, n. 3 .

VELASCO CABALLERO, Francisco (2014): "El nuevo régimen local general y su aplicación diferenciada en las distintas comunidades autónomas", Revista catalana de dret públic, n. ${ }^{\circ}$ 48, págs. 1-23.

VILLAR EZCURRA, Marta (2010): "La analogía en la aplicación de las normas tributarias", en Tratado sobre la Ley General Tributaria: Homenaje a Álvaro Rodríguez Bereijo, coord. por Andrés Báez Moreno, Ed. Aranzadi, págs. 473-786. 
